\title{
Influence of Phosphite Supply in the MS Medium on Root Morphological Characteristics, Fresh Biomass and Enzymatic Behavior in Five Genotypes of Potato (Solanum tuberosum L.)
}

\author{
Richard Dormatey ${ }^{1,2,+}+\mathbb{D}$, Chao Sun ${ }^{1,2,+}$, Kazim Ali ${ }^{1,3} \mathbb{D}$, Tianyuan Qin ${ }^{1,2}$, Derong Xu ${ }^{1,2}$, Zhenzhen Bi ${ }^{1,2}$ \\ and Jiangping Bai ${ }^{1,2, *}$
}

1 Department of Crop Genetics and Breeding, College of Agronomy, Gansu Agricultural University, Lanzhou 730070, China; rmddormatey@gmail.com (R.D.); sunc@gsau.edu.cn (C.S.); kazim76@gmail.com (K.A.); qty1637835362@sina.com (T.Q.); xudr1@sina.com (D.X.); bizz@gsau.edu.cn (Z.B.)

2 Gansu Provincial Key Laboratory of Aridland Crop Science, Lanzhou 730070, China

3 National Institute for Genomics and Advanced Biotechnology, National Agricultural Research Centre, Park Road, Islamabad 45500, Pakistan

* Correspondence: baijp@gsau.edu.cn

+ Richard Dormatey and Chao Sun contributed equally to this work.

check for updates

Citation: Dormatey, R.; Sun, C.; Ali, K.; Qin, T.; Xu, D.; Bi, Z.; Bai, J. Influence of Phosphite Supply in the MS Medium on Root Morphological Characteristics, Fresh Biomass and Enzymatic Behavior in Five Genotypes of Potato (Solanum tuberosum L.). Horticulturae 2021, 7, 265. https://doi.org/ 10.3390/horticulturae7090265

Academic Editors:

Agnieszka Hanaka,

Jolanta Jaroszuk-Ściseł and

Małgorzata Majewska

Received: 11 July 2021

Accepted: 23 August 2021

Published: 26 August 2021

Publisher's Note: MDPI stays neutral with regard to jurisdictional claims in published maps and institutional affiliations.

Copyright: (c) 2021 by the authors. Licensee MDPI, Basel, Switzerland. This article is an open access article distributed under the terms and conditions of the Creative Commons Attribution (CC BY) license (https:/ / creativecommons.org/licenses/by/ $4.0 /)$.

\begin{abstract}
Crop production is threatened by low phosphorus $(\mathrm{P})$ availability and weed interference. Obtaining plant genotypes that can utilize Phosphite (Phi) as fertilizer can supplement phosphates (Pi) while providing an environmentally friendly means of weed control. The study was conducted to determine the tolerance and enzymatic behavior of five potato genotypes to $\mathrm{PO}_{3}$. Explants were regenerated in vitro from two nodal cuttings and cultured on Murashige and Skoog (MS) medium under controlled conditions for 30 days. Matured plantlets were subcultured for 20 days in MS medium containing $(0.25,0.5 \mathrm{mM}) \mathrm{Phi}$ and Pi and No-P (-Phi + -Pi). The results showed significant genotypic variation in tolerance indices among the five genotypes. Atlantic showed greater tolerance to Phi, with highest total root length (50.84\%), root projected area $(75.09 \%)$, root surface area $(68.94 \%)$, root volume $(33.49 \%)$ and number of root forks $(75.66 \%)$. Phi induced an increasing trend in the levels of hydrogen peroxide in the genotypes with the least effect in Atlantic. The comprehensive evaluation analysis confirmed the tolerance of Atlantic genotype with this ranking; Atlantic, Longshu3, Qingshu9, Longshu6 and Gannong2. Antioxidant enzyme activities and proline content also increased significantly under Phi and No-P treatments. The results suggested that potato genotypes with larger root systems may be more tolerant to Phi than genotypes with smaller root systems.
\end{abstract}

Keywords: phosphite stress; antioxidant enzyme; hydrogen peroxide; root morphology; potato; genotypes

\section{Introduction}

Phosphorus $(\mathrm{P})$ is an important macronutrient required by all living organisms and a very important cellular component that plays a crucial role in biological activities [1,2]. Phosphorus is involved in the signaling of target proteins through phosphorylation and dephosphorylation that determine various cellular performances for optimal plant growth [3]. The major $\mathrm{P}$ forms include phosphate and phosphite, which are used in agriculture [4]. Phosphate anions $\left(\mathrm{H}_{2} \mathrm{PO}_{4}{ }^{-}, \mathrm{HPO}_{4}{ }^{2-}\right.$ and $\left.\mathrm{PO}_{4}{ }^{3-}\right)$ are certainly the main forms of $\mathrm{P}$ used by plants for metabolic processes and development, while phosphite is a reduced form of Pi that can be readily taken up by plants through Pi transporters [3]. More than $90 \%$ of the Pi required by plants is supplied by the soil, which provides adequate storage [5]. However, an estimated $80 \%$ of Pi fertilizer applied to soil worldwide is lost through immobilization and conversion to inorganic forms that plants cannot utilize directly [6]. Since $\mathrm{Pi}$ is highly reactive and rapidly transformed by soil microbes, only $20-30 \%$ is effectively 
utilized by plants [7]. According to Gianessi [8], in most soils, weeds and crops compete for the available $\mathrm{Pi}$, resulting in Pi deficiency to meet plant growth requirements. As global demand for food increases, the overuse of $\mathrm{PO}_{4}$ fertilizers and herbicides has become inevitable [9]. This can accelerate the depletion of non-renewable phosphorus reserves, and increase production costs and prices of agricultural products; it also has significant environmental impacts, such as runoff into water bodies, leading to algal blooms, eutrophication, etc. $[10,11]$. Overuse of herbicides in cultivation has led to the emergence of herbicide-resistant superweeds in recent years [12]. Thus, low soil phosphorus availability and herbicide-resistant weeds have been identified as major threats to the long-term sustainability of agriculture $[7,12,13]$, for which an effective long-term solution is urgently needed.

Phosphite anions $\left(\mathrm{H}_{2} \mathrm{PO}_{3}{ }^{-}\right.$and $\left.\mathrm{HPO}_{3}{ }^{2-}\right)$ have high solubility and low soil reactivity. Although plants and various microorganisms cannot utilize Phi, it can be used as a potential target to enhance germplasm for phosphorus utilization by plants [14,15]. Phosphite has an inhibitory effect on plant growth with similar properties to herbicides [16]. The phosphite salt does not pose any risk to human and animal health and is therefore massively used as an effective fungicide in crop production [2]. Thus, phosphite has a direct effect on phytopathogenic fungi by inhibiting mycelial proliferation and reducing conidiogenesis of Fusarium sp. isolated from the rhizosphere of plants [17]. In addition, Phi can act indirectly by stimulating the inherent defense mechanisms of plants to limit pathogen growth [18], and also activate host defense genes that help plants defend against disease [19] and directly suppress the growth of pathogens such as Phytophthora [20-22]. According to Mehta et al. [23] and Thao and Yamakawa [24], Phi anions cannot be utilized by plants as a phosphorus nutrient, although Phi is well taken up by plant leaves and roots. The supply of Phi to plants as a sole source of $P$ fertilizer can hinder plant growth and a higher dose can completely destroy plants [25,26]. Moreover, McDonald, Grant and Plaxton [16] claimed that Phi-treated plants accumulate Phi rapidly in their cells. Phosphite is phloem-mobile and accumulates in sink tissues [27]. Since Phi is not metabolized by plants, it remains in tissues for a long time and consequently disrupts the signal transduction chain that allows plants to detect and respond to Pi deficiency at the molecular level, thereby amplifying the negative effects of Phi $[23,28]$.

On the contrary, the stimulatory effect of Phi mediates structural and biochemical changes in potato periderm and rind [29]. Phi application improved fruit set and yield of Persea americana (avocado) and also restored optimal growth of Pi deficient Citrus species [20]. Again, several reports indicated impressive results of Phi on plant P nutrition, which ultimately increased crop yields [25,30]. When Phi is added to the soil, it comes into contact with microorganisms that help Phi to oxidize to Pi [2]. Thus, following microbial oxidation reactions, Phi may become available to the plant as a P nutrient through this indirect pathway. Interestingly, efforts to generate transgenic plants with microbial genes $(p t x D)$ that allow plants to use Phi as a sole P source have opened new possibilities for the use of this P-containing compound for plant nutrition [30]. In contemporary agriculture, Phi is emerging as a unique biostimulant that improves crop productivity and quality, through direct antibiotic effects on microorganisms and inhibition via enhanced plant defense responses. In addition, Phi induces a variety of abiotic stress tolerance mechanisms, including heat tolerance [31,32]. Obtaining a potato genotype that is tolerant to Phi will enable us to conduct more advanced genetic studies to understand gene functions for subsequent molecular work. In this experiment, we investigated the effects of Phi concentrations, MS medium without $\mathrm{P}$ nutrient (No-P) and sufficient $\mathrm{Pi}$ under in vitro cultures to determine the tolerance of potato genotypes. Nevertheless, there is insufficient information to test the assumption that Phi can stimulate antioxidant enzyme activities and hydrogen peroxide levels. Therefore, the experiment aims to: (1) determine the tolerance of five potato genotypes to Phi stress using tolerance indices and (2) evaluate the responses of antioxidant enzymes in Solanum tuberosum L. plantlets grown in different concentrations of Phi. 


\section{Materials and Methods}

\subsection{Place of the Experiment and Materials}

The experiment was conducted in Gansu Providential key laboratory of Aridland Crop Science, College of Agronomy, Gansu Agricultural University Lanzhou, China $\left(36^{\circ} 03^{\prime} \mathrm{N} ; 103^{\circ} 40^{\prime} \mathrm{E}\right)$. Potato genotypes; Qingshu9, Longshu6, Longshu3, Atlantic and Gannong2, were used in this experiment. The Atlantic genotype is reported to be droughtsusceptible [33,34], the Longshu6 genotype is classified as moderately drought-tolerant [35], while Qingshu9 and Longshu3 were designated as drought-tolerant genotypes.

\subsection{Source of Genotypes and Preparation of In Vitro Explants}

The five potato genotypes were obtained from the laboratory of Crop Improvement and Germplasm Enhancement, Gansu Agricultural University, Lanzhou. Two years of field trials have yielded a wealth of germplasm traits with a large number of sterile tissue culture seedlings for genetic screening. Uniform explants from two nodal cuttings were cultured on the potato growth medium of Murashige and Skoog [36], which contained sucrose $30 \mathrm{gL}^{-1}$ and agar $5 \mathrm{gL}^{-1}$. The $\mathrm{pH}$ was adjusted to 5.8 and the medium was autoclaved at $121^{\circ} \mathrm{C}$ at $151 \mathrm{~b}$ psi for $25 \mathrm{~min}$. Cultures were maintained in a growth room at $25 \pm 1{ }^{\circ} \mathrm{C}$, $16 \mathrm{~h}$ photoperiod, active photosynthetic radiation of $45 \mu \mathrm{mol}$ photons $\mathrm{m}^{-2} \mathrm{~s}^{-1}$, and relative humidity of $55-66 \%$ for a 30-day growth period. Plantlets were harvested after 30 days and used for subsequent experiments. Uniform cuttings of each with two axillary buds were subcultured in an ethanol-sterilized chamber with laminar air flow and propagated in MS medium supplemented with final concentrations of $(0.25,0.5 \mathrm{mM}) \mathrm{Phi}$ and Pi and No-P supply, in sterilized glass vials $(120 \times 50 \mathrm{~mm})$. Five cuttings of explants were cultured in each vial, which was tightly sealed with the lids and kept at $25 \pm 1{ }^{\circ} \mathrm{C}$ in the growth room.

\subsection{Experimental Design and Treatments}

A $5 \times 5$ factorial trial in a completely randomized design with 3 replicates was conducted in a controlled growth room. Treatments included five potato genotypes, two concentrations $(0.25$ and $0.5 \mathrm{mM})$ each of phosphite and phosphate, and a medium without $\mathrm{P}$ fertilizer, representing (No-P). We used $0.5 \mathrm{mM} \mathrm{Pi}$ as a control. Fifty vials per genotype were cultured, with each vial containing five explants. After 20 days, the plantlets were examined for physio-morphological indices. The rest of the plantlets were plunged into liquid nitrogen and immediately preserved at $-80{ }^{\circ} \mathrm{C}$ for biochemical analysis.

\subsection{Measurements of Data}

\subsubsection{Physio-Morphological Parameters}

Physiological parameters, such as shoot and root length $(\mathrm{cm})$, were determined with a ruler by randomly selecting three plants from each replication and averaging these data. The number of roots and leaves were counted on each selected plant. Fresh stem weight, fresh root weight and total plant weight $(\mathrm{g})$ were also measured using an electronic balance, with subsequent calculation of root to shoot ratio and tolerance biomass index for each genotype.

The roots of the sampled plantlets were carefully detached from the stems, washed in distilled water and scanned using a root scanner (STD) 4800, EPSON, Quebec City, QC, Canada and the root morphological indices such as total root length (TRL), root projected area (RPA), root surface area (RSA), root volume (RV), number of root tips (NRT), number of root forks (NRF) were calculated using root image analysis software Win RHIZO version 5.0 (Regent Instruments, Inc., Quebec City, QC, Canada).

\subsubsection{Tolerance Indexes Determination}

Based on the formula of Wilkins [37], the Phi tolerance indices (TIs) of the root system, which clearly indicate the tolerance of the root systems to Phi stress, were calculated according to the modifications of Dawuda et al. [38]. Since Phi uptake has direct effects on the different measured root morphological indices and plant tolerance to Phi stress, Phi TI 
was determined at the end of the experiment for each root index. Considering the score of TI, we classified the genotype with the largest TI for most of the calculated indices as the most tolerant genotype among the five potato genotypes studied. The formula of TI is as follows: $\mathrm{TI}=$ index under Phi stress/index without Phi stress $\times 100$.

\subsubsection{Determination of Hydrogen Peroxide and Malonaldehyde Contents in Samples}

The content of hydrogen peroxide $\left(\mathrm{H}_{2} \mathrm{O}_{2}\right)$ in the shoot samples was determined as described by Junglee et al. [39], with minor modifications. A $0.1 \mathrm{~g}$ fresh shoot sample was crushed using a mortar and pestle in liquid nitrogen. The homogenate was transferred to a $2 \mathrm{~mL}$ centrifuge tube and kept in an ice bath. An amount of $1.5 \mathrm{~mL}$ of $0.1 \%$ Trichloroacetic acid (TCA) was added and the uniform mixture was centrifuged at $12,000 \times g$ for $15 \mathrm{~min}$ at $4{ }^{\circ} \mathrm{C}$. The supernatant $0.5 \mathrm{~mL}$ was carefully mixed with $0.5 \mathrm{~mL}$ Phosphate Buffer Saline (PBS) and $1 \mathrm{~mL} \mathrm{KI}(1 \mathrm{M})$ at $7.0 \mathrm{pH}$. The mixture was kept at $28^{\circ} \mathrm{C}$ for one hour. The absorbance was measured using a spectrophotometer (model U-5100, Seya-Namioka, Hitachi Hightechnologies, Minato-ku, Tokyo, Japan) at $390 \mathrm{~nm}$. The contents of $\mathrm{H}_{2} \mathrm{O}_{2}$ were determined with reference to the standard curve $\left(0,1,2,3,4\right.$ and $\left.5 \mathrm{mmol}^{-1}\right)$. Malonaldehyde (MDA) Content Assessment Lipid peroxidation was measured by calculating the amount of MDA emitted using the technique for thiobarbituric acid (TBA) as presented in Hodges et al. [40]. Preserved fresh shoot samples of $0.15 \mathrm{~g}$ were crushed using a mortar and pestle and $4.5 \mathrm{~mL}$ of $10 \%$ TCA was added. Then, the homogenized substance was centrifuged at $500 \times g$ for $15 \mathrm{~min}$ at $4{ }^{\circ} \mathrm{C}$. The supernatant was transferred to a centrifuge bottle and the volume $(\mathrm{V})$ was recorded. Two $\mathrm{mL}$ of the supernatant was then mixed with $2 \mathrm{~mL}$ of $0.6 \%$ TBA. The homogenized mixture was warmed in boiling water for $20 \mathrm{~min}$, the reaction stopped in an ice bath, and centrifuged at $5000 \times g$ for $10 \mathrm{~min}$. The supernatant $(2 \mathrm{~mL})$ of V1 was transferred to a cuvette. The absorbance of the supernatant was measured at 450, 532, and $600 \mathrm{~nm}$, respectively. The MDA content was estimated according to the following formula: MDA concentration $(\mu \mathrm{mol} / \mathrm{L})=6.45 \times(\mathrm{A} 532-\mathrm{A} 600)-0.56 \times \mathrm{A} 450$. MDA content $(\mu \mathrm{mol} / \mathrm{g} \mathrm{FW})=\mathrm{C}(\mu \mathrm{mol} / \mathrm{L}) \times \mathrm{V}(\mathrm{L}) \times \mathrm{V} 1(\mathrm{~mL}) / 2 \mathrm{~mL} \times \mathrm{M}(\mathrm{g} \mathrm{FW})$.

\subsubsection{Determination of Antioxidant Enzymes Activities and Proline Contents in Shoots}

Enzyme samples were prepared from frozen tissue preserved at $-80^{\circ} \mathrm{C}$. Each shoot sample (approximately $0.5 \mathrm{~g}$ ) was crushed in liquid nitrogen using a mortar and pestle and homogenized in $5 \mathrm{~mL}$ of $0.1 \mathrm{M}$ phosphate buffer ( $\mathrm{pH} 7.8$ ) containing $0.5 \mathrm{mM}$ ethylenediamine tetraacetic acid (EDTA). Each homogenate was centrifuged at $12,000 \times g$ for $15 \mathrm{~min}$ at $4{ }^{\circ} \mathrm{C}$. The supernatant was collected for determination of enzymatic activity. The activities of catalase (CAT), peroxidase (POD) and superoxide dismutase (SOD) in the shoot homogenate were determined using a reagent kit (Nanjing Jiancheng Bioengineering Institute, Nanjing, China) following the manufacturer's instructions. The principles of these kits are summarized as follows:

Catalase activity was determined by the spectrophotometric ammonium molybdate method, in which ammonium molybdate rapidly stops the $\mathrm{H}_{2} \mathrm{O}_{2}$ degradation reaction, catalyzed CAT, as the remaining $\mathrm{H}_{2} \mathrm{O}_{2}$ reaction produces a yellow compound that can be examined by absorbance at $405 \mathrm{~nm}$. A catalase unit activity was classified as the amount of enzyme in $1 \mathrm{~g}$ of fresh tissue that reduces $1 \mu \mathrm{mol}$ of $\mathrm{H}_{2} \mathrm{O}_{2}$ per minute at $37^{\circ} \mathrm{C}$.

SOD activity was calculated according to the method of Dhindsa et al. [41]. The method is based on photochemical reduction of SOD-motivated Nitrotetrazolium Blue Chloride (NBT) at $560 \mathrm{~nm}$. A unit of SOD activity was well defined as the amount of enzyme that inhibits $50 \%$ of the oxidation.

Peroxidase activity was determined by catalysis of hydrogen peroxide by POD, observing absorbance changes at $420 \mathrm{~nm}$ and estimating the activity of POD. One unit of POD activity was defined as the amount of enzyme in $1 \mathrm{~g}$ of fresh plant tissue reducing $1 \mu \mathrm{g}$ of $\mathrm{H}_{2} \mathrm{O}_{2}$ at $37^{\circ} \mathrm{C}$ per min. Proline content was determined according to the method of Bates et al. [42]. Fresh shoot samples weighing $0.15 \mathrm{~g}$ were crushed with $4.5 \mathrm{~mL}$ of $3 \%$ $(w / v)$ sulfosalicylic acid homogenization and the homogenate was heated in boiling water 
for $30 \mathrm{~min}$. This was then filtered through $0.2 \mu \mathrm{m}$ filter paper. The extract and the volume of extract were designated as $\mathrm{Vt}$. The supernatant was used to determine the amount of proline. The reaction mixture consisted of $2 \mathrm{~mL}$ of plant extract and an appropriate amount of ninhydrin glacial acetic acid. The test tubes containing the substance were heated in boiling water for $30 \mathrm{~min}$. The reaction was quenched with the addition of toluene in an ice bath. The substance was shaken vigorously on vortex mixer for 15-30 s and divided into two phases (upper and lower chromophase). The upper chromophase (toluene) was carefully aspirated with a pipette, and absorbance was taken at $520 \mathrm{~nm}$. The amounts of proline were measured from the standard curve and expressed as $\mu \mathrm{g} \cdot \mathrm{g}^{-1} \mathrm{FW}$. The amount of proline was calculated as: Proline content $(\mu \mathrm{g} / \mathrm{gFW})=\mathrm{C} \times \mathrm{Vt} /(\mathrm{V} \times \mathrm{W})$.

\subsection{Analyses of Data}

All data collected were analyzed using SPSS software 22.0 version (IBM Corp., Chicago, IL, USA). Means of treatments were separated by Duncan's multiple range tests with a probability of $5 \%$. The distribution of means was presented in the figures using standard deviations. All graphs were created using GraphPad Prism version 8.0 (GraphPad Software, Inc., San Diego, CA, USA). Principal component analysis (PCA) was performed using the software PAST-PAlaeontological Statistics, version 1.34. To confirm the tolerance status of potato genotypes to Phi, comprehensive evaluation analysis based on PCA was carried out using R software package Statistics, version 3.5.3, considering the following formula:

$$
\mu\left(X_{i}\right)=(X i-X \min ) /\left(X \max -X_{\min }\right) i=1,2,3 \ldots n
$$

In Formula (1), $\mu(\mathrm{Xi})$ refers to the membership function value of the i-th comprehensive index, and $\mathrm{Xi}$ refers to the $\mathrm{i}$-th. Comprehensive index value, $\mathrm{Xmax}$ refers to the maximum value of the $\mathrm{i}$-th, comprehensive index, $X \min$ refers to the $\mathrm{i}$-th, the minimum value of a comprehensive index. Calculation of the weighting of each comprehensive index:

$$
\mathrm{Wi}=\frac{\mathrm{Pi}}{\sum_{\mathrm{i}=1}^{\mathrm{m}} \mathrm{Pi}} \quad \mathrm{i}=1,2,3 \ldots \mathrm{n}
$$

In Formula (2), Wi represents the importance of the i-th comprehensive index in all comprehensive indices. In terms of degree and weight, $\mathrm{Pi}$ is the contribution rate of the $\mathrm{i}$-th comprehensive index of each genotype. Calculation of comprehensive evaluation value (D).

$$
\mathrm{D}=\sum_{\mathrm{i}=1}^{\mathrm{m}}[\mu(\mathrm{Xi}) \times \mathrm{Wi}] \quad \mathrm{i}=1,2,3 \ldots \mathrm{n}
$$

In Formula (3), D represents the phosphite tolerance of different potato genotypes. The $\mathrm{D}$ value is obtained by calculating the weighted membership function value. The larger the value of $\mathrm{D}$, the more the Phi tolerance.

\section{Results}

3.1. Influence of Phosphite and Phosphate on Physiological Parameters of Five Potato Genotypes after 20 Days' Growth Period

The results showed significant $(p<0.01)$ genotype $\mathrm{x}$ phosphorus source and rates interaction effect on all physiological parameters (Figure 1a-d). Phosphite stress significantly reduced the growth of potato genotypes in this study. Reduction in growth was observed in both roots and shoots resulting in reduction in fresh biomass and fresh root to shoot ratio. Mostly all physiological indices across all genotypes were decreased by $\mathrm{PO}_{3}$ $(0.25$ and $0.5 \mathrm{mM})$ and No-P, but Atlantic genotype was least affected. At Phi $0.5 \mathrm{mM}$, the decrease in leaf number was least $(40.67 \%)$ in Longshu6 and greatest (57.16\%) in Qingshu9. The least $(61.93 \%)$ and greatest $(81.73 \%)$ decrease in the number of roots occurred in Atlantic and Gannong2, respectively. The least (58.18, 6.22\%) and greatest (69.95, 91.33\%) decrease in shoot and root length was observed in Atlantic and Gannong2 genotypes, respectively. Moreover, similar results were observed among the five genotypes with 
respect to $\mathrm{PO}_{3}(0.25 \mathrm{mM})$, but the decrease in physiological parameters due to Phi stress was more pronounced at 0.5 compared to $0.25 \mathrm{mM}$. In the treatment without P supply, physiological growth was also decreased in all the five potato genotypes except Atlantic and Longshu3, which recorded increase in root length as compared to their respective control. Compared to the control, the application of $\mathrm{PO}_{3}$ at $(0.25$ and $0.5 \mathrm{mM})$ and No-P had a negative effect on the fresh biomass indices of the genotypes (Table 1). Application of $\mathrm{PO}_{3}(0.25 \mathrm{mM})$ to genotype Gannong2 caused greater reductions in FRW $(80.95 \%)$, FSW $(82.48 \%)$ and TPW $(82.00 \%)$. In addition, smaller reductions were observed in FSW (43.24\%) and TPW $(30.20 \%)$, and there was a slight increase in FRW (7.41\%) of Atlantic genotype. The application of Phi $(0.5 \mathrm{mM})$ gave similar results with a slight difference in severity compared to the results obtained with $0.25 \mathrm{mM}$. Thus, application of higher rates of Phi could be lethal to potato plantlets. Maximum decrease in FRW (87.21\%), FSW $(83.94 \%)$ and TPW $(80.50 \%)$ and minimum decrease in FRW (14.81\%), FSW (60.81\%) and TPW (48.51\%) were observed in potato genotypes Gannong2 and Atlantic, respectively.
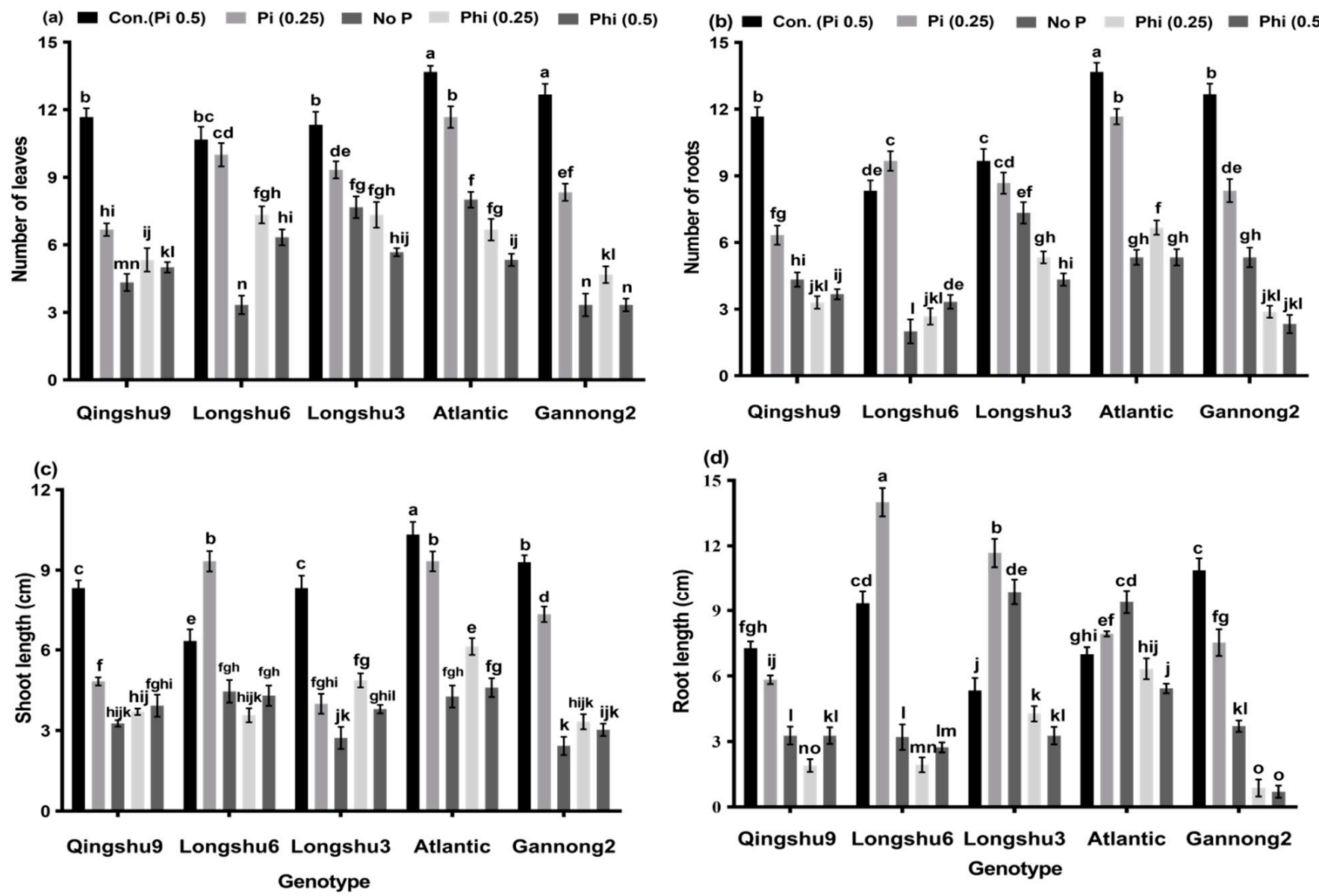

Figure 1. Effect of Phi, Pi and No-P on (a) number of leaves, (b) number of roots, (c) shoot length (cm), and (d) root length $(\mathrm{cm})$ of five potato genotypes grown in modified MS media containing 0.25 and $0.5 \mathrm{mM}$ Phi and Pi and No-P supply for 20 days. Values denote the mean of 3 replicates, \pm standard deviation (SD). Means obtained with the same letter in the minuscule do not differ by Duncan Multiple range's test $(p \leq 0.05)$. 
Table 1. Effect of Phi, Pi and No-P supply on fresh biomass, root/shoot ratio and biomass tolerance index of five potato genotypes studied under in vitro conditions.

\begin{tabular}{|c|c|c|c|c|c|c|}
\hline \multirow[b]{2}{*}{ Genotype } & \multicolumn{4}{|c|}{ Biomass Accumulation (g) } & \multirow{2}{*}{$\begin{array}{c}\text { Root/Shoot } \\
\text { Ratio }\end{array}$} & \multirow[b]{2}{*}{ * BTI (\%) } \\
\hline & Treatment & $\begin{array}{l}\text { Fresh Root } \\
\text { Weight }\end{array}$ & $\begin{array}{c}\text { Fresh Shoot } \\
\text { Weight }\end{array}$ & $\begin{array}{c}\text { Fresh Plant } \\
\text { Weight }\end{array}$ & & \\
\hline \multirow[t]{5}{*}{ Qingshu9 } & Con.Pi 0.5 & $0.087 \pm 0.002^{\mathrm{a}}$ & $0.156 \pm 0.001^{\mathrm{a}}$ & $0.243 \pm 0.003^{\mathrm{ab}}$ & $0.560 \pm 0.006^{\text {ef }}$ & 100 \\
\hline & Pi0.25 mM & $0.067 \pm 0.004^{b}$ & $0.143 \pm 0.0008^{\mathrm{a}}$ & $0.210 \pm 0.004^{b c}$ & $0.467 \pm 0.031 \mathrm{fgh}$ & 96.42 \\
\hline & No-P & $0.033 \pm 0.001$ ef & $0.054 \pm 0.0008^{c}$ & $0.087 \pm 0.002^{\mathrm{fg}}$ & $0.611 \pm 0.019$ de & 35.80 \\
\hline & Phi0.25 mM & $0.019 \pm 0.004 \mathrm{gh}$ & $0.064 \pm 0.001 \mathrm{bc}$ & $0.083 \pm 0.003^{\mathrm{fg}}$ & $0.297 \pm 0.072^{\mathrm{jk}}$ & 30.04 \\
\hline & Phi $0.5 \mathrm{mM}$ & $0.018 \pm 0.006^{\mathrm{gh}}$ & $0.065 \pm 0.001 \mathrm{bc}$ & $0.083 \pm 0.006^{\mathrm{g}}$ & $0.277 \pm 0.085^{\mathrm{jk}}$ & 30.04 \\
\hline \multirow[t]{5}{*}{ Longshu6 } & Control & $0.087 \pm 0.0006^{\mathrm{a}}$ & $0.154 \pm 0.002^{\mathrm{a}}$ & $0.241 \pm 0.002^{\mathrm{ab}}$ & $0.565 \pm 0.015$ ef & 100 \\
\hline & Pi0.25 mM & $0.097 \pm 0.0006^{\mathrm{a}}$ & $0.157 \pm 0.001^{\mathrm{a}}$ & $0.254 \pm 0.001^{\mathrm{a}}$ & $0.618 \pm 0.007 \mathrm{de}$ & 105.39 \\
\hline & No-P & $0.025 \pm 0.001 \mathrm{fg}$ & $0.062 \pm 0.003^{c}$ & $0.087 \pm 0.003^{\mathrm{fg}}$ & $0.403 \pm 0.033$ ghi & 36.51 \\
\hline & Phi0.25 mM & $0.014 \pm 0.0006^{\mathrm{gh}}$ & $0.054 \pm 0.0006^{\mathrm{c}}$ & $0.068 \pm 0.0006^{\mathrm{g}}$ & $0.259 \pm 0.015^{\mathrm{k}}$ & 27.80 \\
\hline & Phi $0.5 \mathrm{mM}$ & $0.026 \pm 0.001 \mathrm{fg}$ & $0.057 \pm 0.001^{\mathrm{c}}$ & $0.083 \pm 0.001 \mathrm{~g}$ & $0.456 \pm 0.018^{\text {fghi }}$ & 34.44 \\
\hline \multirow[t]{5}{*}{ Longshu3 } & Control & $0.048 \pm 0.001^{\mathrm{cd}}$ & $0.147 \pm 0.001^{\mathrm{c}}$ & $0.195 \pm 0.002^{c}$ & $0.327 \pm 0.001^{\mathrm{jk}}$ & 100 \\
\hline & $\mathrm{Pi} 0.25 \mathrm{mM}$ & $0.085 \pm 0.0006^{\mathrm{a}}$ & $0.089 \pm 0.0006^{b}$ & $0.174 \pm 0.000^{\mathrm{cd}}$ & $0.955 \pm 0.013^{b}$ & 89.23 \\
\hline & No-P & $0.067 \pm 0.002^{b}$ & $0.055 \pm 0.001^{\mathrm{c}}$ & $0.122 \pm 0.003$ ef & $1.218 \pm 0.007^{\mathrm{a}}$ & 63.08 \\
\hline & Phi0.25 mM & $0.037 \pm 0.0006^{\text {def }}$ & $0.064 \pm 0.0006^{b c}$ & $0.101 \pm 0.001^{\mathrm{fg}}$ & $0.578 \pm 0.002^{\text {ef }}$ & 57.95 \\
\hline & Phi $0.5 \mathrm{mM}$ & $0.024 \pm 0.001 \mathrm{fg}$ & $0.048 \pm 0.002^{c}$ & $0.072 \pm 0.001^{g}$ & $0.500 \pm 0.037 \mathrm{efg}$ & 36.92 \\
\hline \multirow[t]{5}{*}{ Atlantic } & Control & $0.054 \pm 0.0006^{b c}$ & $0.148 \pm 0.0006^{\mathrm{a}}$ & $0.202 \pm 0.000^{c}$ & $0.365 \pm 0.005$ hij & 100 \\
\hline & Pi 0.25 mM & $0.067 \pm 0.001^{b}$ & $0.135 \pm 0.001^{\mathrm{a}}$ & $0.202 \pm 0.0006^{\mathrm{c}}$ & $0.496 \pm 0.012^{\mathrm{fg}}$ & 100 \\
\hline & No-P & $0.057 \pm 0.001^{b c}$ & $0.058 \pm 0.0006^{\mathrm{c}}$ & $0.115 \pm 0.002 e^{e f}$ & $0.983 \pm 0.019^{b}$ & 56.93 \\
\hline & Phi0.25 mM & $0.058 \pm 0.0006^{b c}$ & $0.084 \pm 0.0006^{b}$ & $0.142 \pm 0.0006^{\mathrm{de}}$ & $0.690 \pm 0.010^{d}$ & 69.80 \\
\hline & Phi $0.5 \mathrm{mM}$ & $0.046 \pm 0.001^{\mathrm{cde}}$ & $0.058 \pm 0.001^{\mathrm{c}}$ & $0.104 \pm 0.002$ efg & $0.793 \pm 0.005^{\mathrm{d}}$ & 51.48 \\
\hline \multirow[t]{5}{*}{ Gannong2 } & Control & $0.063 \pm 0.001^{b}$ & $0.137 \pm 0.001^{\mathrm{a}}$ & $0.200 \pm 0.001^{c}$ & $0.460 \pm 0.006^{\text {fghi }}$ & 100 \\
\hline & $\mathrm{Pi} 0.25 \mathrm{mM}$ & $0.067 \pm 0.001^{b}$ & $0.135 \pm 0.001^{\mathrm{a}}$ & $0.202 \pm 0.0006^{c}$ & $0.496 \pm 0.012^{\mathrm{fg}}$ & 101.00 \\
\hline & No-P & $0.024 \pm 0.001 \mathrm{fg}$ & $0.044 \pm 0.001^{\mathrm{cd}}$ & $0.068 \pm 0.001^{g}$ & $0.545 \pm 0.031$ ef & 34.00 \\
\hline & Phi0.25 mM & $0.016 \pm 0.0006^{\mathrm{fg}}$ & $0.052 \pm 0.001^{\mathrm{c}}$ & $0.078 \pm 0.001 \mathrm{~g}$ & $0.500 \pm 0.032$ efg & 18.00 \\
\hline & Phi0.5 mM & $0.008 \pm 0.001^{\mathrm{h}}$ & $0.022 \pm 0.003^{\mathrm{d}}$ & $0.039 \pm 0.003^{h}$ & $0.350 \pm 0.052^{\mathrm{ijk}}$ & 19.50 \\
\hline
\end{tabular}

Data indicate the mean \pm SD of 3 biological replications and were tested for significance using Duncan's multiple range tests. Individual columns marked with different lowercase letters indicate significant differences $(p<0.01)$. * The BTI was not subjected to an analysis of variance.

Fresh biomass indices of No-P treated potato genotypes were decreased due to the absence of $\mathrm{Pi}$ in the growth media. The effect of Pi deficiency was more pronounced in the shoots than in the roots of the five potato genotypes. The greatest decrease in fresh biomass indices (FRW, FSW and TPW) was recorded in genotype Gannong2, while the least occurred in genotype Longshu3. Moreover, the negative effects of Phi and No-P on growth of all genotypes were measured in biomass tolerance index (BTI). The result showed that Atlantic genotype had the highest (70.39 and 51.49\%) BTIs, followed by LS3 (51.79 and $36.92 \%$ ), while the lowest (34.16 and $15.00 \%$ ) BTIs were recorded in Qinshu9 and Gannong2 genotypes at Phi $(0.25$ and $0.5 \mathrm{mM})$. In No-P treatment, genotype Longshu3 recorded the highest value $(62.56 \%)$ followed by Atlantic (56.93\%) and the lowest value (34.00\%) was observed in Gannong2. Among Phi-treated genotypes in terms of root to shoot ratio (RSR), Atlantic recorded the highest value (0.79 and 0.69$)$, and the lowest value (0.26 and $0.28)$ was recorded in Longshu6 and Qingshu9 at $(0.25$ and $0.5 \mathrm{mM})$. In No-P treatment, Longshu3 had the highest value (1.22), while Longshu6 had the lowest (0.40). However, in Pi-sufficient genotypes, the number of leaves, number of roots, shoot length and root length were increased compared to their respective controls. The maximum increase was recorded in the Atlantic genotype. Fresh biomass indices showed similar results in all the five genotypes as compared to the respective controls. The lowest root, shoot, and total plant weights were recorded in Qingshu9 and Longshu3, while maximum increase was recorded in Gannong2 and Longshu6 genotypes, respectively. 
3.2. Effects of Phosphite, Phosphate and No-P Supply on Root Morphological Characteristics of Five Potato Genotypes for 20 Days Growth Period

There were significant $(p<0.01)$ genotype $\mathrm{x}$ phosphite interaction effects on total root length (TRL), root projected area (RPA), root surface area (RSA), root volume (RV), number of root tips (NRT), and number of root forks (NRF) (Figure 2). In general, root morphological indices were decreased in all five genotypes, with the Atlantic genotype being the least affected. The decrease in TRL due to Phi effects was least (32.86 and 43.17\%) in Atlantic and greatest (80.85 and 80.93\%) in Longshu6 and Gannong2 at Phi (0.25 and $0.5 \mathrm{mM}$ ), respectively. The least decrease in RPA (15.62 and 24.81\%) was recorded in Atlantic while the greatest $(68.57$ and $75.85 \%)$ was observed in Gannong2 at $(0.25$ and $0.5 \mathrm{mM})$. Moreover, the least (16.86 and 30.85\%) and greatest ( 85.57 and $84.50 \%$ ) decrease in RSA was observed in Atlantic, Longshu3 and Longshu6 and Gannong2 genotypes, respectively. The least (53.85 and 66.51\%) decrease in RV occurred in Atlantic, while the greatest (82.08 and $84.70 \%$ ) was observed in Longshu6 and Gannong2. Moreover, the least decrease (29.49 and $24.34 \%$ ) of NRT occurred in Atlantic and Longshu3 genotypes, while the greatest (85.02 and $89.86 \%$ ) was observed in Longshu6 and Gannong2, at 0.25 and $0.5 \mathrm{mM}$, respectively. The least (16.57 and $31.06 \%$ ) decrease in NRF was observed in Atlantic, while the greatest (83.94 and $80.01 \%$ ) was measured in Longshu6 and Gannong2, at Phi 0.25 and $0.5 \mathrm{mM}$, respectively. The decrease in root morphological parameters observed in the five genotypes was due to Phi effects, which caused a decrease in the size of the root and shoot systems of the genotypes. The root morphological indices of the treatment without $\mathrm{P}$ supply were also decreased in all five genotypes. Mainly due to the absence of Pi in the No-P treatment, this reduced the root growth of the susceptible genotypes, while the tolerant genotypes developed longer root systems. The least decrease in morphological indices was observed in Longshu3 and Atlantic, while the greatest decrease was observed in Gannong2 and Longshu6 genotypes. However, Pi-sufficient potato genotypes exhibited much higher root morphological indices than genotypes grown under Phi and No-P. Root morphological indices were slightly increased in Pi-sufficient plants of the five potato genotypes. Among the genotypes: Longshu3 and Longshu6 recorded the highest increase, while Atlantic and Qingshu9 had the least increase in all root morphological indices. 

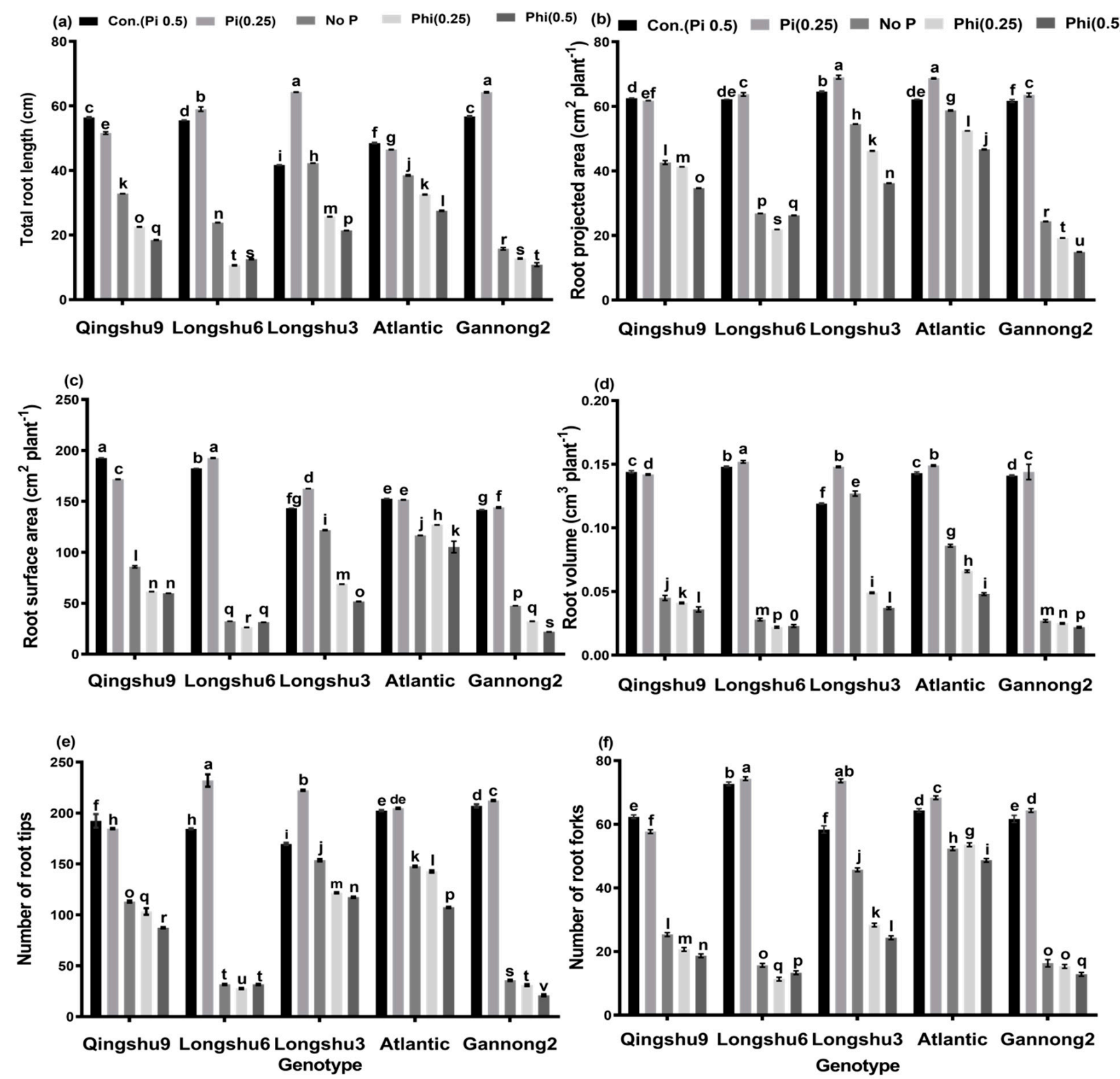

Figure 2. Effect of $\mathrm{PO}_{3}, \mathrm{PO}_{4}$ and No-P on (a) Total root length (b) Root projected area (c) Root surface area (d) Root volume (e) Number of root tips and (f) Number of root forks of five potato genotypes grown for 20 days in medium containing concentrations of $0.25,0.5 \mathrm{mM} \mathrm{PO}_{3}$ and $\mathrm{PO}_{4}$ and No-P. Values symbolize the mean of 3 replicates \pm standard deviation (SD). Means followed by the same lowercase letter do not differ among treatments by Duncan Multiple range's test $(p \leq 0.05)$.

\subsection{Tolerance of the Five Potato Genotypes to Phosphite Stress}

There were significant differences $(p<0.01)$ in the tolerance indices (TIs) among the five potato genotypes at $0.25,0.5 \mathrm{mM}$ and No-P (Figure 3). The result showed that after the plantlets were grown for 20 days in the Phi media, Atlantic had the highest TI for majority of the measured indices such as TRL (56.84\%), RPA (75.09\%), RSA (68.94\%), RV (33.49\%) and NRF $(75.66 \%)$ at Phi $(0.5 \mathrm{mM})$. Considering this result, among the five potato genotypes tested, the Atlantic genotype proved to be the most tolerant, except TI for NRT, which was highest in Longshu3 (69.16\%). However, compared to Atlantic, the other genotypes obtained lower TI values and were found to be susceptible to $\mathrm{PO}_{3}$ stress. 


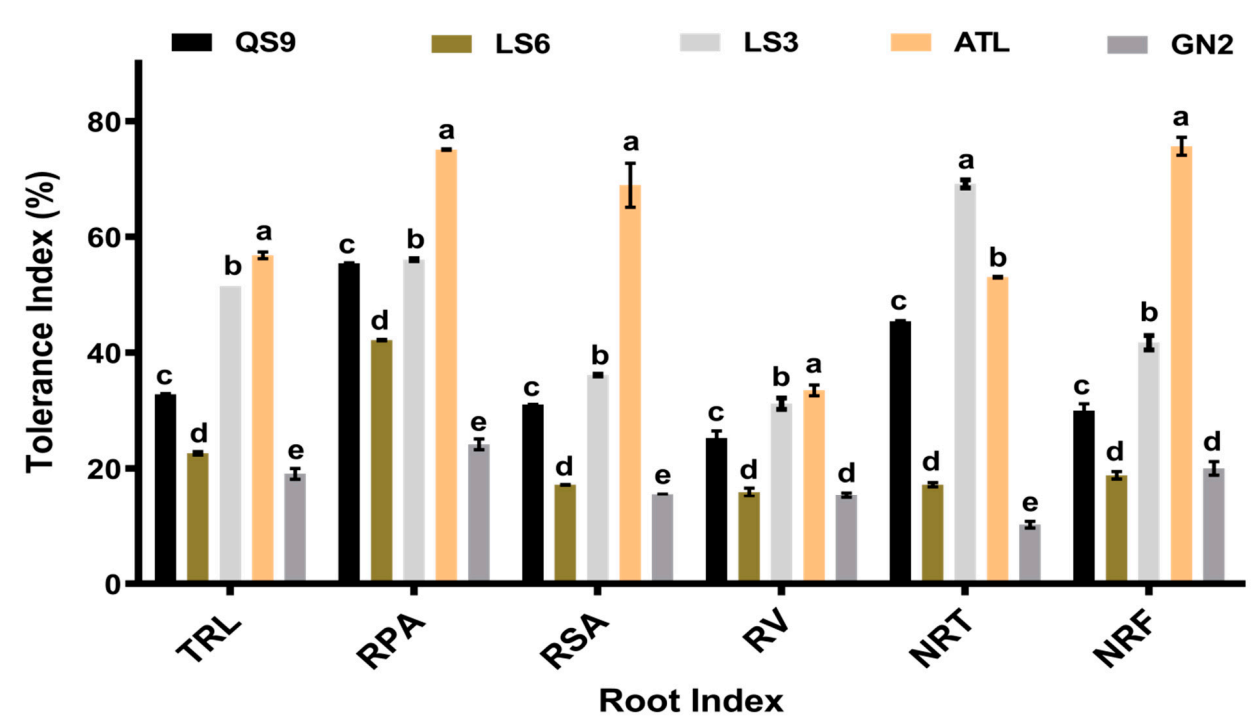

Figure 3. Root $\mathrm{PO}_{3}$ tolerance indexes (\%) of five potato genotypes under $0.5 \mathrm{mM}$ Phi treatment. Qingshu9 = QS9; Longshu6 = LS6; Longshu3 = LS3; Atlantic = ATL and Gannong2 = GN2. Total root length $=$ TRL; Root projected area $=$ RPA; Root surface area $=\mathrm{RSA}$; Root volume $=\mathrm{RV}$; Number of root tips $=$ NRT and Number of root forks $=$ NRF. Values represent the mean of 3 replicates \pm standard deviation (SD). Bars associated with different lowercase letters show significant differences by Duncan Multiple Range's test $(p \leq 0.05)$.

\subsection{Content of $\mathrm{H}_{2} \mathrm{O}_{2}$ and $M D A$ in the Shoots}

There was a significant $(p<0.001)$ genotype $\mathrm{x}$ phosphite $\mathrm{x}$ rate effect on $\mathrm{H}_{2} \mathrm{O}_{2}$ and MDA content in shoots of potato genotypes (Figure 4). Compared to the control plants, Phi increased $\mathrm{H}_{2} \mathrm{O}_{2}$ and MDA content in the shoots of the five genotypes by 50.96 to $68.84 \%$ and 43.63 to $70.17 \%$ at $0.25 \mathrm{mM}, 56.01$ to $71.64 \%$ and 48.32 to $71.48 \%$ at $0.5 \mathrm{mM}$, respectively. The highest $\mathrm{H}_{2} \mathrm{O}_{2}$ and MDA values were observed in GN2, followed by genotypes Longshu6, Qingshu9 and Longshu3. The lowest $\mathrm{H}_{2} \mathrm{O}_{2}$ and MDA levels were observed in Atlantic genotypes at Phi 0.25 and $0.5 \mathrm{mM}$, respectively. Moreover, similar results were obtained with respect to treatment without $\mathrm{P}$ supply in the five potato genotypes. However, $\mathrm{Pi}-$ sufficient plants in all five potato genotypes exhibited low $\mathrm{H}_{2} \mathrm{O}_{2}$ and MDA contents, compared to genotypes under Phi stress.
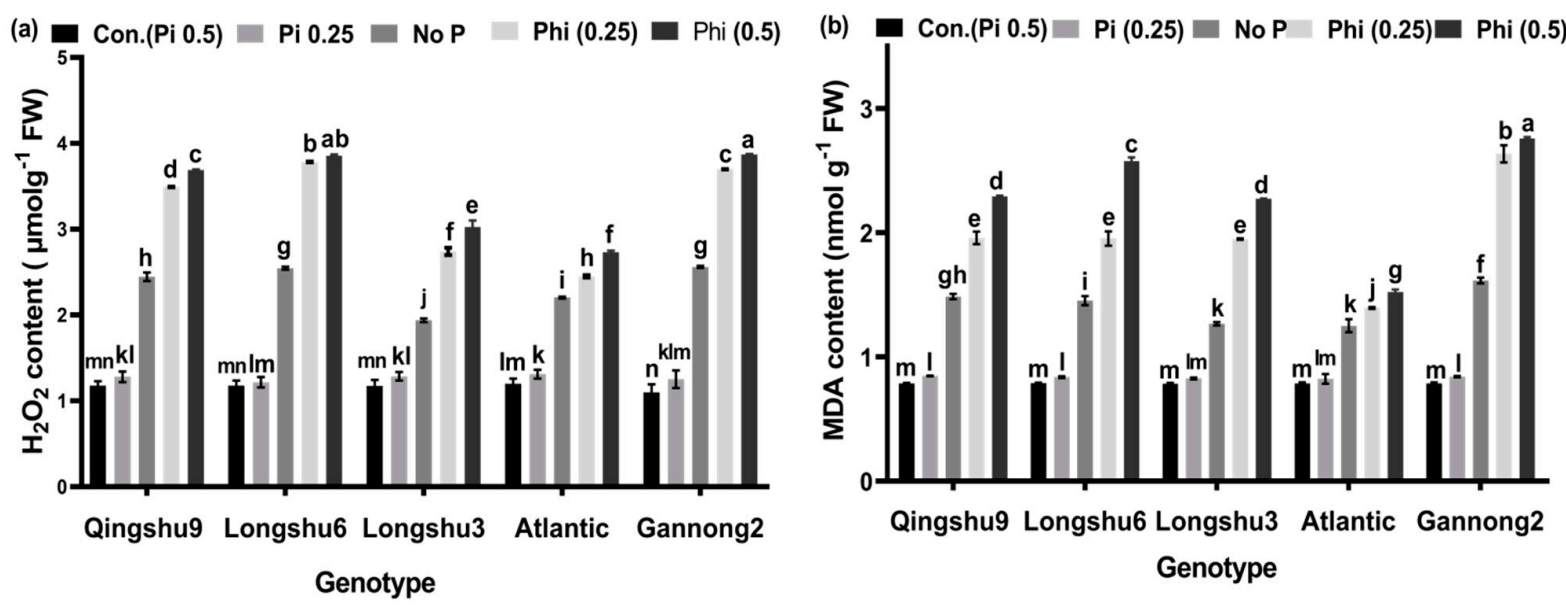

Figure 4. Effects of Phi, Pi and No-P on $\mathrm{H}_{2} \mathrm{O}_{2}$ and MDA content; (a) Shows $\mathrm{H}_{2} \mathrm{O}_{2}$ content and (b) shows MDA content in the shoots of potato genotypes. Values denote the mean of 3 replicates \pm standard deviation (SD). Duncan multiple range test $(p \leq 0.05)$ shows large differences between bars assigned to different lowercase letters. 


\subsection{Antioxidant Enzymes Activities and Content of Proline}

The effect of genotype $x$ Phi interaction on antioxidant enzyme activities as well as the levels of proline was also significant $(p<0.01)$ in the shoots of the five potato genotypes (Figure 5). Compared with the individual control plants, Phi stress increased the proline contents in the shoots of all genotypes by 80.11 to $81.09 \%$ and 76.79 to $79.21 \%$ at Phi 0.5 and $0.25 \mathrm{mM}$, respectively. Moreover, the activities of CAT, POD and SOD increased by 46.07 to $55.54 \%, 50.77$ to $53.14 \%$ and 54.39 to $63.09 \%$, respectively, in all genotypes at $0.5 \mathrm{mM}$. The greatest increase in CAT activity was observed in the ATL genotype, while the LS6 genotype had the greatest POD and SOD activities. Similar increases in CAT, POD and SOD activities were observed in all genotypes at Phi $(0.25 \mathrm{mM})$ and in No-P supplied potato genotypes.
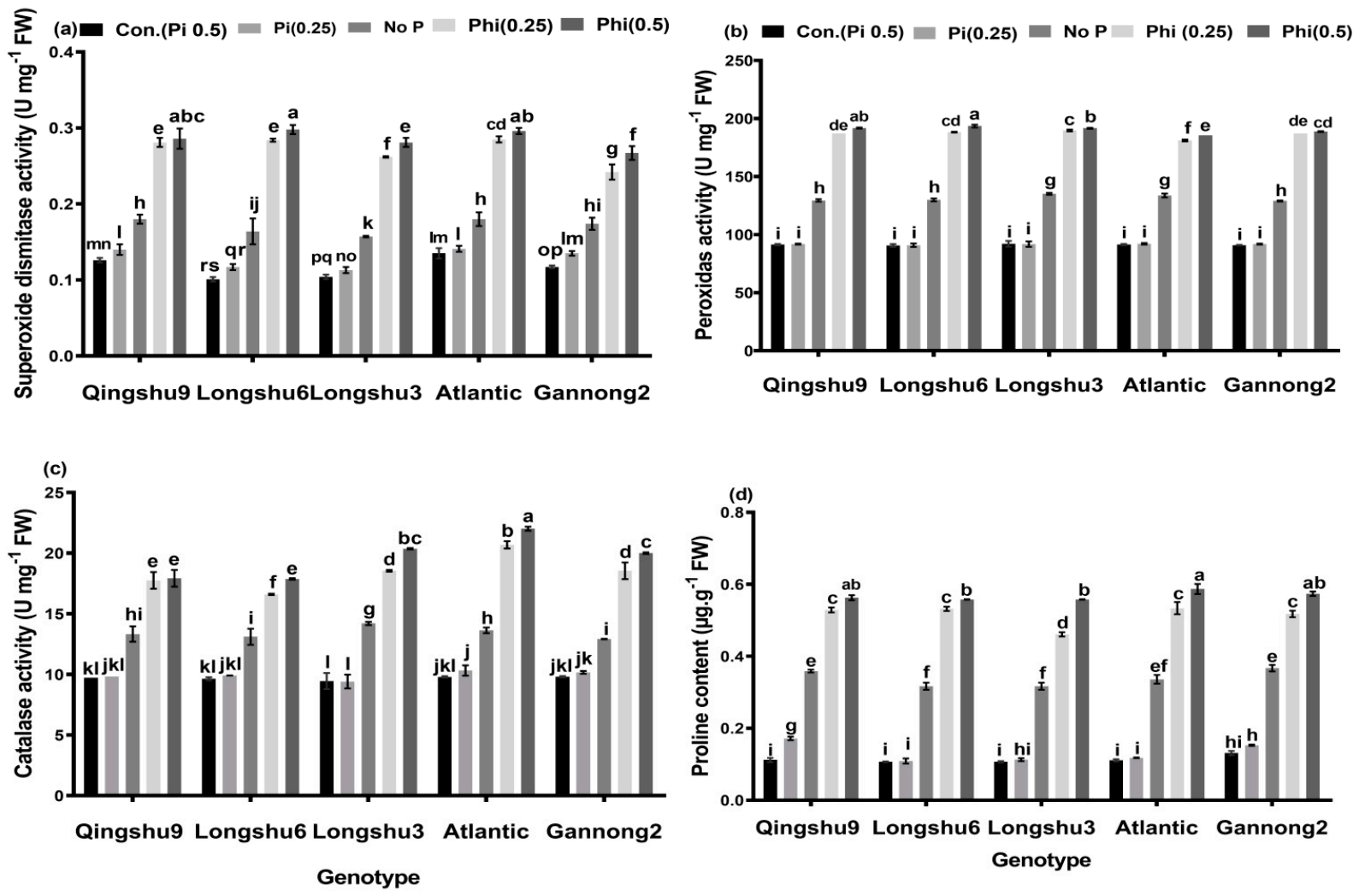

Figure 5. Phi and Pi effects on enzyme activities and contents of proline; (a) Shows the activities of SOD; (b) Shows the activities of POD; (c) Shows the activities of CAT; (d) Contents of proline. Values denote the mean of 3 replications \pm standard deviation (SD). Bars associated with different lowercase letters show significant differences by Duncan Multiple Range's test $(p \leq 0.05)$.

\subsection{Relationships between Root Morphological Characteristics, Fresh Biomass and Biochemical Responses of the Five Potato Genotypes under Phi Stress}

The correlation matrix between root morphological indices, fresh biomass, antioxidant enzyme activities, MDA, $\mathrm{H}_{2} \mathrm{O}_{2}$ and proline of the five potato genotypes under Phi stress were significantly negative (Table 2). All six root morphological indices were negatively correlated with MDA, $\mathrm{H}_{2} \mathrm{O}_{2}$, CAT, SOD, POD and Pro., e.g., TRL showed a significant negative correlation with MDA, $\mathrm{H}_{2} \mathrm{O}_{2}, \mathrm{CAT}$, SOD, POD and Pro $\left(\mathrm{r}=-0.87^{* *}, \mathrm{r}=-0.94\right.$ **, $\mathrm{r}=-0.80^{* *}, \mathrm{r}=-0.83^{* *}, \mathrm{r}=-0.87^{* *}$ and $\left.\mathrm{r}=-0.89^{* *}\right)$. The fresh biomass, i.e., FRW, FSW and TPW were also negatively correlated with $\mathrm{MDA}, \mathrm{H}_{2} \mathrm{O}_{2}, \mathrm{CAT}$, SOD, POD and Pro, e.g., FRW was negatively correlated with MDA, $\mathrm{H}_{2} \mathrm{O}_{2}, \mathrm{CAT}$, SOD, POD and Pro $(\mathrm{r}=-0.67$ *, $\mathrm{r}=-0.75^{* *}, \mathrm{r}=-0.62 *, \mathrm{r}=-0.69^{*}, \mathrm{r}=-0.69^{*}$ and $\left.\mathrm{r}=-0.72 * *\right)$. Principal component analysis (PCA) was used to determine the effects of Phi and No-P on root morphological indices, fresh biomass, antioxidant enzymes, MDA, $\mathrm{H}_{2} \mathrm{O}_{2}$ and proline (Table 3). The cumulative contribution percentage of the two principal components associated with the 
response is $90.16 \%$, the eigenvalue of $\mathrm{PC} 1$ is 8.818 and the contribution percentage is $62.98 \%$. The eigenvectors include TRL, FRW, RPA, RSA, FRSR, NRF, RV and NRT. The eigenvalue of PC2 is 3.971 , which corresponds to $27.18 \%$, where the higher charges are CAT, SOD, MDA, POD and Pro show significant separations between the treatments. Genotype LS3 had the highest score followed by ATL, QS9, LS6 and GN2 at No-P, along PC1. On the other hand, ATL recorded the highest score followed by LS3, while GN2 had the lowest score at Phi $(0.25$ and $0.5 \mathrm{mM})$, along PC2. The treatments No-P and Phi (0.25 and 0.5) were far from the origin, implying that Phi and No-P strongly affected the root morphological characteristics and fresh biomass of potato genotypes (Figure 6). The comprehensive evaluation according to the principal component analysis of Phi tolerance was calculated using Formula (1) to calculate different products based on the two independent comprehensive indicators to obtain the membership function value $\mu(\mathrm{Xi})$ of each comprehensive index. Table 4 shows that, using the higher concentration of Phi $(0.5 \mathrm{mM})$ treatment, in the same comprehensive index $\mathrm{CI}(1)$, Atlantic $\mu(\mathrm{X} 1)$ is the largest, with 0.937 , indicating that Atlantic has the highest Phi tolerance on the $\mathrm{CI}(1)$ comprehensive index. According to the contribution rate of each comprehensive index, the weights of the two comprehensive indicators in terms of Phi tolerance were calculated using Formula (2) as follows: 0.699, 0.301. In addition, Formula (3) was used to calculate the Phi tolerance value according to the D value, and the Phi tolerance among the five genotypes was ranked as: Atlantic > Longshu3 > Qingshu9 > Longshu6 > Ganannong 2, respectively.

Table 2. Correlation matrix describing the relationship between root morphological characteristics, fresh biomass and activities of antioxidant enzymes, $\mathrm{MDA}, \mathrm{H}_{2} \mathrm{O}_{2}$ and proline in potato plants under Phi stress at 20 days after treatments.

\begin{tabular}{cccccccccc}
\hline Index & TRL & RPA & RSA & RV & NRT & NRF & FRW & FSW & TPW \\
\hline MDA & $-0.87^{* *}$ & $-0.77^{* *}$ & $-0.81^{* *}$ & $-0.74^{* *}$ & $-0.78^{* *}$ & $-0.78^{* *}$ & $-0.67^{*}$ & $-0.75^{* *}$ & $-0.84^{* *}$ \\
$\mathrm{H}_{2} \mathrm{O}_{2}$ & $-0.94^{* *}$ & $-0.90^{* *}$ & $-0.92^{* *}$ & $-0.86^{* *}$ & $-0.90^{* *}$ & $-0.91^{* *}$ & $-0.75^{* *}$ & $-0.79^{* *}$ & $-0.92^{* *}$ \\
$\mathrm{CAT}$ & $-0.80^{* *}$ & $-0.71^{* *}$ & $-0.74^{* *}$ & $-0.68^{* *}$ & $-0.70^{* *}$ & $-0.70^{* *}$ & $-0.62^{*}$ & $-0.74^{* *}$ & $-0.81^{* *}$ \\
$\mathrm{SOD}$ & $-0.83^{* *}$ & $-0.71^{* *}$ & $-0.75^{* *}$ & $-0.71^{* *}$ & $-0.71^{* *}$ & $-0.73^{* *}$ & $-0.69^{*}$ & $-0.72^{* *}$ & $-0.78^{* *}$ \\
$\mathrm{POD}$ & $-0.87^{* *}$ & $-0.77^{* *}$ & $-0.82^{* *}$ & $-0.75^{* *}$ & $-0.77^{* *}$ & $-0.80^{* *}$ & $-0.69^{*}$ & $-0.76^{* *}$ & $-0.85^{* *}$ \\
Pro & $-0.89^{* *}$ & $-0.80^{* *}$ & $-0.84^{* *}$ & $-0.77^{* *}$ & $-0.80^{* *}$ & $-0.82^{* *}$ & $-0.72^{* *}$ & $-0.81^{* *}$ & $-0.89^{* *}$ \\
\hline
\end{tabular}

MDA = Malonaldehyde; $\mathrm{H}_{2} \mathrm{O}_{2}=$ Hydrogen peroxide; $\mathrm{CAT}=$ Catalase; $\mathrm{SOD}=$ Superoxide dismutase; $\mathrm{POD}=$ Peroxidase; Pro = Proline; $\mathrm{TRL}=$ Total root length; RPA = Root projected area; RSA = Root surface area; RV = root volume; NRT = Number of root tips; $\mathrm{NRF}=$ Number of root forks; FRW $=$ Fresh root weight; FSW $=$ Fresh shoot weight and TPW $=$ Total plant weight. ${ }^{*}=$ significant difference at $5 \%$ probability level; ${ }^{* *}=$ significant difference at $1 \%$ probability level.

Table 3. Principal Component, loadings related to Phi treatments variable and explained variance for final sampling.

\begin{tabular}{lcc}
\hline \multicolumn{1}{c}{ Principal Component } & PC $\mathbf{~ P C ~ 2 ~}$ \\
\hline Total root length & 0.323 & 0.098 \\
Root projected area & 0.284 & 0.234 \\
Root surface area & 0.290 & 0.235 \\
Root volume & 0.260 & 0.224 \\
Number of root tips & 0.259 & 0.266 \\
Number of root forks & 0.270 & 0.279 \\
Fresh root weight & 0.298 & 0.044 \\
Fresh root/shoot ratio & 0.295 & 0.095 \\
Malonaldehyde & -0.232 & 0.353 \\
Hydrogen peroxide & -0.319 & 0.044 \\
Catalase & -0.162 & 0.409 \\
Superoxide dismutase & -0.229 & 0.374 \\
Peroxidases & -0.238 & 0.348 \\
Proline & -0.245 & 0.339 \\
Eigenvalue & 8.818 & 3.805 \\
Contribution rate \% & 62.98 & 27.18 \\
Cumulative contribution rate \% & 62.98 & 90.16 \\
\hline
\end{tabular}




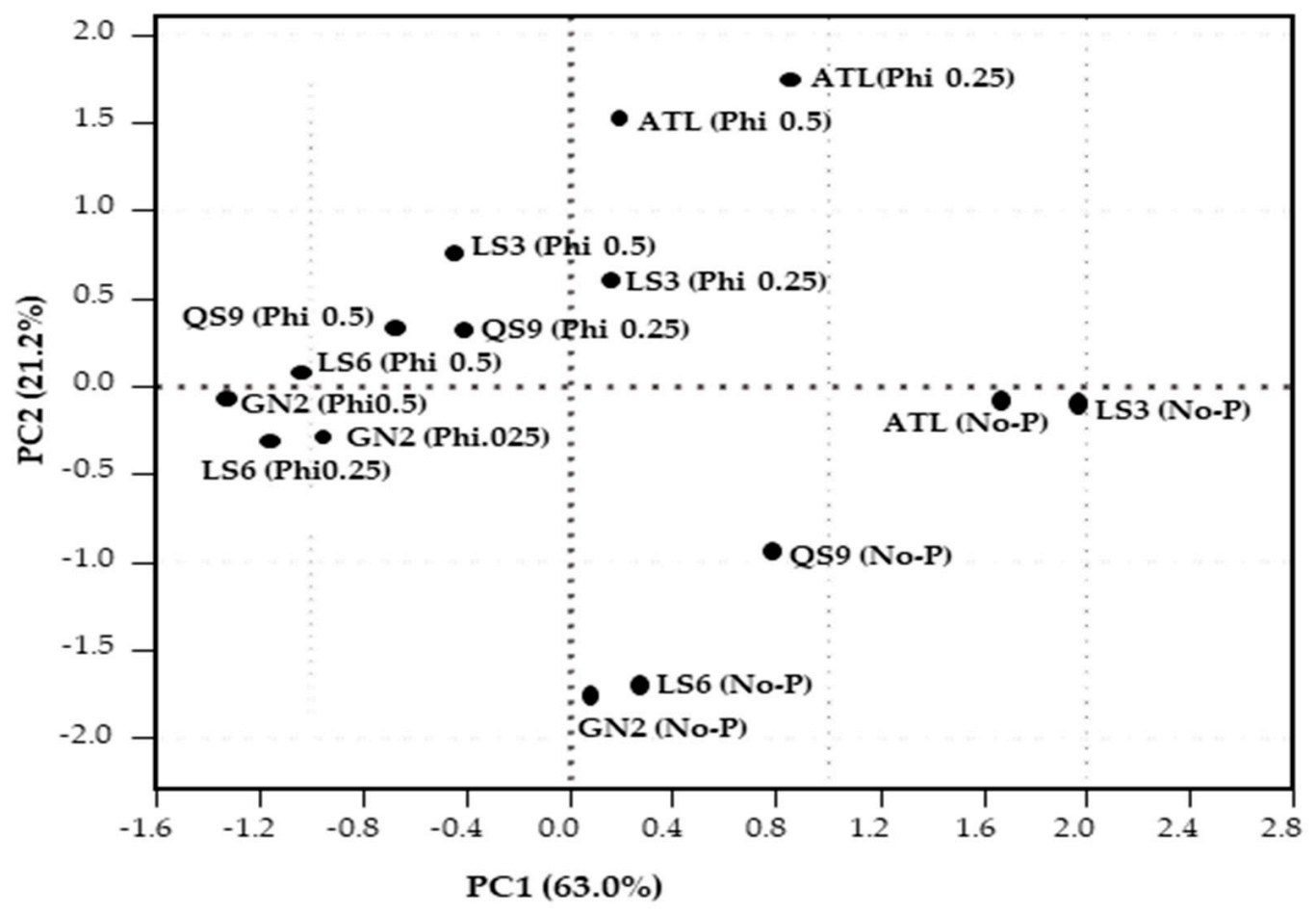

Figure 6. Scatter diagrams of arranged first two main components; PC1/PC2.

Table 4. Comprehensive index (C1), index weight $\mu(X)$, and comprehensive evaluation (D) of five potato genotypes under Phi and No-P stresses.

\begin{tabular}{|c|c|c|c|c|c|c|c|}
\hline Genotype & Treatment & $\mathrm{CI}(1)$ & $\mathrm{CI}(2)$ & $\mu\left(X_{1}\right)$ & $\mu\left(X_{2}\right)$ & $\begin{array}{c}\text { Comprehensive } \\
\text { Assessment Value (D) }\end{array}$ & Ranking \\
\hline \multirow[t]{3}{*}{ Qingshu9 } & No-P & 2.394 & -1.940 & 0.639 & 0.235 & 0.517 & \\
\hline & Phi 0.25 & -1.252 & 0.648 & 0.277 & 0.597 & 0.373 & \\
\hline & Phi 0.5 & -2.079 & 0.689 & 0.195 & 0.603 & 0.318 & 3 \\
\hline \multirow[t]{3}{*}{ Longshu6 } & No-P & 0.832 & -3.531 & 0.484 & 0.013 & 0.342 & \\
\hline & Phi 0.25 & -3.567 & -0.622 & 0.047 & 0.419 & 0.159 & \\
\hline & Phi 0.5 & -3.172 & 0.169 & 0.086 & 0.539 & 0.220 & 4 \\
\hline \multirow[t]{3}{*}{ Longshu3 } & No-P & 6.034 & -0.266 & 1.000 & 0.469 & 0.849 & \\
\hline & Phi 0.25 & 0.474 & 1.228 & 0.448 & 0.678 & 0.517 & \\
\hline & Phi 0.5 & -1.384 & 1.539 & 0.264 & 0.721 & 0.402 & 2 \\
\hline \multirow[t]{3}{*}{ Atlantic } & No-P & 5.160 & -0.213 & 0.913 & 0.477 & 0.782 & \\
\hline & Phi 0.25 & 2.649 & 3.536 & 0.663 & 1.000 & 0.765 & \\
\hline & Phi 0.5 & 0.589 & 3.088 & 0.469 & 0.937 & 0.604 & 1 \\
\hline \multirow[t]{3}{*}{ Gannong2 } & No-P & 0.249 & -3.627 & 0.426 & 0.000 & 0.297 & \\
\hline & Phi 0.25 & -2.876 & -0.582 & 0.116 & 0.425 & 0.209 & \\
\hline & Phi 0.5 & -4.043 & -0.117 & 0.000 & 0.499 & 0.148 & 5 \\
\hline Weight & & 0.699 & 0.301 & & & & \\
\hline
\end{tabular}

\section{Discussion}

In vitro regeneration studies are considered an efficient technique for defining the regulatory mechanisms of stress tolerance in potato explants. Several studies have shown the importance of in vitro shoot regeneration in plant breeding programs for economic drives [43]. To select more resistant cultivars for production, plant breeders need knowledge on how to improve regeneration of explants grown under stress conditions [44,45]. Five genotypes with different drought stress tolerance were selected based on sound data on their drought tolerance availability. These genotypes are widely grown and consumed in China. Therefore, it is important for farmers, consumers and breeders to understand their tolerance to $\mathrm{PO}_{3}$. In addition, we need to investigate whether the mechanism of 
drought tolerance in potato differs from the mechanism that may support $\mathrm{PO}_{3}$ tolerance. In this study, we investigated the effects of Phi, Pi deficiency and Pi sufficiency on potato plant growth. Our data showed that Phi at concentrations of 0.25 and $0.5 \mathrm{mM}$ severely inhibited plant growth, whereas Pi adequate plants grew normally across the five genotypes. We found that the number of leaves, roots, shoot length and root length of five potato genotypes cultured in Phi media were significantly reduced compared to those propagated in Pi-adequate media. Similar negative growth effects of Phi on B. nigra seedlings and $B$. napus cell suspension cultures have been documented previously [46]. Plants cultured in Phi media are very sensitive to Phi and show signs of toxicity such as leaf chlorosis and stunted growth $[16,24,30]$. These findings coincided with our observation in the present study. The observed decrease in plant growth in the presence of Phi could be related to two important morphological changes in the plants. Reduced internode length was an identifying feature of Phi-treated plants. Plant height was significantly reduced in Phi-treated plants in all five genotypes, whereas P-sufficient plants appeared normal in the presence of Pi concentrations $(0.25$ and $0.5 \mathrm{mM})$. The second important cause was a significant decrease in root development in Pi deficiency-treated plants and Phi treated plants. However, potato genotypes Atlantic and Longshu3 showed a modest increase in root development rate compared with the other genotypes studied at 0.25 and $0.5 \mathrm{mM}$ Phi.

We further found that Phi at 0.25 and $0.5 \mathrm{mM}$ altered the fresh biomass parameters such as fresh root weight, fresh shoot weight, total plant weight and root to shoot ratio in all genotypes as compared to Pi-sufficient plants. The reduction in fresh biomass of the five genotypes caused by Phi toxicity was more pronounced in fresh root weight than fresh shoot weight at both concentrations. This reduction had a large effect on total plant weight, resulting in reduced plant growth and development in Phi-treated plants, as previously documented for B. nigra plants [47]. The reduced root to shoot ratio observed in the majority of genotypes is consistent with the deleterious effect of Phi on root hair production, anthocyanin accumulation in the shoot, and stimulation of enzymes induced by Pi deficiency [48]. In summary, our experiment in potato is consistent with previous reports on the biological effects of Phi in Brassica sp. [49] and in tomato [50]. Under Phi supply conditions, even a low dose $(0.25 \mathrm{mM})$ was sufficient to induce a decrease in fresh biomass. The majority of the potato genotypes showed a decrease in root/shoot ratio compared to Pi-sufficient plants, except Atlantic and Longshu3, which showed a marginal increase. Furthermore, the effect of Pi deficiency on potato genotypes was studied using a medium containing -Phi + -Pi, which corresponds to No-P. All genotypes under this treatment showed a significant decrease in fresh biomass except Atlantic and Longshu3 which showed an increase in root weight compared to the other genotypes. The considerable increase in root length and root weight of these genotypes resulted in a slight increase in root to shoot ratio compared to the respective controls. This observation corroborates the findings of Lambers and Plaxton [51], who observed that the absence of Pi in the growth media altered root phenotypes such as increased root hair density and root length as well as metabolism (e.g., release of carboxylates and Pi scavenging enzymes into the rhizosphere). The mechanism for overcoming the $\mathrm{P}$ deficit in growth media containing No-P plants is explained by an increase in root length [4,46,52]. Moreover, several studies have shown that plants under water stress increase root length in deeper profiles and that the main difference between shallow and deeper rooting genotypes is manifested in the stress conditions imposed in each case $[53,54]$. Biomass tolerance index (BTI) was calculated for each genotype in relation to the stress variables $(0.25,0.5 \mathrm{mM}$ and No-P) to clearly define the tolerance of potato genotypes to Phi. The result showed that in No-P treatment, Longshu3 genotype had the highest BTI, followed by Atlantic, and Gannong2 had the lowest BTI. At Phi 0.25 and $0.5 \mathrm{mM}$, the Atlantic genotype had the highest BTI followed by Longshu3 genotype, while Gannong2 genotype had the lowest BTI. 
Root growth and shoot growth are correlated with each other. According to Polania et al. [55], shoot growth supplies carbon and some hormones to the roots, while root growth supplies water, nutrients and hormones to the shoot. Despite the fact that no previous study has explicitly investigated the utility of root morphological traits for plant performance under Phi stress, the results of the current study suggest that Phi interference reduces root morphological traits in all genotypes except the Atlantic genotype. It has been suggested that the ability of Phi to limit Arabidopsis development is due to the competitive inhibition of Pi uptake and the inability of plants to readily utilize Phi through oxidation to $\mathrm{Pi}$ [46]. Phi cannot enter P metabolic pathways unless it is converted to Pi [16,56]. Moreover, the growth of plants cultivated in the Phi treatments was comparable to that of plants grown under the No-P supply treatment in terms of root morphological indices. These results confirm the findings of Lee et al. [57] for Ulva lactuca, Schroetter et al. [58] for Zea mays, Thao et al. [59] for Brassica rapa, Avila et al. [60] for Zea mays, Zambrosi et al. [61] for Citrus spp., and Hirosse et al. [62] for Ipomoea batatas. These researchers observed that Phi anion does not replace Pi anion in P nutrition of plants. They added that the use of Phi as the sole source of $P$ resulted in a significant reduction in plant development compared to treatments with insufficient Pi fertilization. Root morphological traits such as architecture, branching, root volume, root hair length and density were found to have reflective effects on nutrient uptake from nutrient sources, which could be used to determine plant tolerance under stress conditions. According to Dawuda et al. [38], the size of root system of lettuce plants influenced their tolerance to cadmium stress in nutrient solution. The results of this study showed that the addition of Phi $(0.25$ and $0.5 \mathrm{mM})$ to MS media decreased the TRL, RPA, RSA, RV, NRT and NRF of all potato genotypes studied. This consequently reduced the size of root systems of most genotypes except Atlantic. Other researchers have found that plant uptake of $\mathrm{P}$ and other nutrients depends on root surface area, root system length and lateral roots to capture a large volume of nutrients in the soil/growth medium [63-65]. In addition, our results show that the Atlantic genotype, which had the larger root system, had root tolerance indices to Phi stress at both concentrations compared with the rest of the genotypes, which had the smallest root systems. The tolerance of the Atlantic genotype to Phi stress was confirmed by the largest tolerance indices for TRL, RPA, RSA, RV, and NRF. The larger root system possessed by Atlantic probably enhanced the uptake of other trace nutrients in the growth media, which contributed to its tolerance. The results of this study are in agreement with those of Wang et al. [66], who postulated that soybean genotypes with larger root systems are more tolerant to cadmium stress. Pandey et al. [67] also reported that genotype PDM-139, a green Gram genotype, with larger root surface area and root volume was the more tolerant genotype to low $\mathrm{P}$ compared to those with smaller root surface area and root volume. Several other reports suggest that larger root surface area, root volume, and root hair length of plants under P-stressed growth conditions are characteristics of tolerant genotypes [68,69].

In addition, plant tolerance to Phi-stress was also determined by the hydrogen peroxide $\left(\mathrm{H}_{2} \mathrm{O}_{2}\right)$ content formed during stress exposure. Increased formation of reactive oxygen species (ROS) such as $\mathrm{H}_{2} \mathrm{O}_{2}$ induces oxidative stress due to the toxicity of Phi [70]. Zhang et al. [71] postulated that Vicia sativa, which had the lowest $\mathrm{H}_{2} \mathrm{O}_{2}$ content was more tolerant than Phaseolus aureus which had higher $\mathrm{H}_{2} \mathrm{O}_{2}$ content when both were exposed to cadmium stress. According to Oyarburo et al. [72], $\mathrm{H}_{2} \mathrm{O}_{2}$ accumulation in leaves is reduced, antioxidant enzyme activities are increased, gene expression is upregulated and accumulation of glucanases and chitinases is induced, which correlates positively with stress tolerance of the plant. In our current study, Phi interference was observed to increase the hydrogen peroxide content in the shoots of the five potato genotypes. Nevertheless, the Atlantic genotype had the lowest increase in $\mathrm{H}_{2} \mathrm{O}_{2}$ content, indicating that Atlantic is more tolerant to Phi stress than the other genotypes tested. These results indicate that potato genotypes with larger root systems are more tolerant to Phi stress than genotypes with smaller root systems. Antioxidant enzymes play a critical role in plant cell defense against stress-induced cell damage caused by the formation of free radicals, mainly in the form of 
ROS. As a result, it has been suggested that increasing antioxidant enzyme activity may improve plant growth and yield. This result is in agreement with Ramos et al. [73], who indicated that increased SOD and CAT activity induced by low selenium concentrations increased leaf yield of Lactuca sativa L. Avila et al. [4] noted that CAT activity was low in Pi-sufficient plants but high by $71 \%$ in Phi-treated plants. Our current experiment provided similar results: the activities of antioxidant enzymes (e.g., SOD, POD and CAT) increased in all five genotypes in the presence of Phi and No-P treated plants, but decreased in Pi-sufficient plants. These antioxidant enzymes are involved in the detoxification of reactive oxygen species. Recent research has shown that Phi-anion can induce molecular changes that promote stress tolerance, such as activation of guaiacol peroxidase activity and lignin biosynthesis in maize [60], and structural and biochemical changes in periderm and cortex of potato tubers [20]. On the other hand, studies on the effects of Phi on antioxidant enzymes are still rare. All morphological variables of roots were significantly negatively correlated with antioxidant enzyme activities, $\mathrm{MDA}, \mathrm{H}_{2} \mathrm{O}_{2}$ and Pro. Fresh biomass indices also showed significant negative correlation with antioxidant enzyme activity, $\mathrm{MDA}, \mathrm{H}_{2} \mathrm{O}_{2}$ and Pro. The negative correlations observed under Phi stress indicated that Phi had a deleterious effect on potato root morphology and fresh biomass indices. To further confirm the tolerant potato genotype to Phi stress, a comprehensive evaluation analysis was conducted based on principal component analysis. The results evaluated the genotypes in this order: Atlantic, Longshu3, Qingshu9, Longshu6 and Gannong2.

\section{Conclusions}

Roots are responsible for the uptake of water and inorganic nutrients and are the primary organs affected by phosphite stress. Therefore, adaptation of roots to phosphite stress affects shoot response, physiological functions and plant growth. In the present study, the responses of five potato genotypes to $0.25,0.5 \mathrm{mM}$ Phi and $\mathrm{Pi}$, and No-P were investigated. The results showed that Phi stress and No-P supply significantly reduced the size of root and shoot systems of the five potato genotypes tested. Nevertheless, the Atlantic genotype with the largest root system showed the highest tolerance to Phi stress by exhibiting the highest tolerance index values for total root length, root projected area, root surface area, root volume, number of root forks, and fresh biomass tolerance. $\mathrm{H}_{2} \mathrm{O}_{2}$ and MDA levels increased in shoots of all genotypes, but Atlantic genotype showed the least increase, indicating greater tolerance to Phi stress. Major antioxidant enzymes such as CAT, POD and SOD activities and proline content increased under stress conditions. Greater tolerance parameters and lower $\mathrm{H}_{2} \mathrm{O}_{2}$ contents were obtained from the Atlantic potato genotype under Phi stress, suggesting that potato genotypes with larger root systems may be more tolerant to Phi stress. The tolerance character of the Atlantic genotype was confirmed by comprehensive evaluation analysis using principal component analysis. The obtained results may be very useful for the selection of the genetically modified potato plants using the $p t x D$ selection marker gene. However, the concentration and accumulation of $\mathrm{P}$ in shoot and root of Pi starved plants were not determined in the present study. The determination of this index will contribute to a better understanding of the mechanism of the negative effect of Phi anion on the physiological and morphological growth of potato genotypes. Therefore, future research should focus on the concentration and accumulation of $\mathrm{P}$ in shoot and root of plants grown under Phi stress and also determine the details of the molecular and genetic mechanisms of Phi tolerance in potato genotypes, especially in genotypes with relatively large root systems.

Author Contributions: Conceptualization, R.D. and C.S.; methodology, R.D. and C.S.; soft-ware, T.Q. and D.X.; validation, K.A. and Z.B.; formal analysis, R.D. and C.S.; investigation, R.D. and C.S.; resources, J.B.; data curation, D.X.; writing—original draft preparation, R.D., K.A. and C.S.; writing-review and editing, R.D., K.A. and C.S.; visualization, Z.B.; supervision, J.B.; project administration, J.B.; funding acquisition, J.B. All authors have read and agreed to the published version of the manuscript. 
Funding: This work was supported by the National Natural Science Foundation of China (Grant No. 32060502 and 31960442), the Special Fund for Discipline Construction of Gansu Agricultural University (GAU-XKJS-2018-085, GAU-XKJS -2018-084), the special Fund for Talents of Gansu agricultural University (Grant No. 2017RCZX-44) and the Gansu Provincial Department of Education Fund (2019B-073).

Data Availability Statement: Not applicable.

Conflicts of Interest: The authors declare no conflict of interest.

\section{References}

1. Kalayu, G. Phosphate solubilizing microorganisms: Promising approach as biofertilizers. Int. J. Agron. 2019, 2019, 1-7. [CrossRef]

2. Achary, V.M.M.; Ram, B.; Manna, M.; Datta, D.; Bhatt, A.; Reddy, M.K.; Agrawal, P.K. Phosphite: A novel P fertilizer for weed management and pathogen control. Plant Biotech. J. 2017, 15, 1493-1508. [CrossRef] [PubMed]

3. Manna, M.; Achary, V.M.M.; Islam, T.; Agrawal, P.K.; Reddy, M.K. The development of a phosphite-mediated fertilization and weed control system for rice. Sci. Rep. 2016, 6, 24941. [CrossRef] [PubMed]

4. Ávila, F.W.; Faquin, V.; da Silva Lobato, A.K.; Ávila, P.A.; Marques, D.J.; Silva Guedes, E.M.; Tan, D.K.Y. Effect of phosphite supply in nutrient solution on yield, phosphorus nutrition and enzymatic behavior in common bean ('Phaseolus vulgaris' L.) Plants. Aust. J. Crop Sci. 2013, 7, 713.

5. Heuer, S.; Gaxiola, R.; Schilling, R.; Herrera-Estrella, L.; López-Arredondo, D.; Wissuwa, M.; Delhaize, E.; Rouached, H. Improving phosphorus use efficiency: A complex trait with emerging opportunities. Plant J. 2017, 90, 868-885. [CrossRef] [PubMed]

6. Yang, L.; Yang, Z.; Zhong, X.; Xu, C.; Lin, Y.; Fan, Y.; Wang, M.; Chen, G.; Yang, Y. Decreases in soil P availability are associated with soil organic $\mathrm{P}$ declines following forest conversion in subtropical China. CATENA 2021, 205, 105459. [CrossRef]

7. Brödlin, D.; Kaiser, K.; Kessler, A.; Hagedorn, F. Drying and rewetting foster phosphorus depletion of forest soils. Soil Biol. Biochem. 2019, 128, 22-34. [CrossRef]

8. Gianessi, L.P. The increasing importance of herbicides in worldwide crop production. Pest Manag. Sci. 2013, 69, 1099-1105. [CrossRef] [PubMed]

9. Parry, M.A.; Hawkesford, M.J. Food security: Increasing yield and improving resource use efficiency. Proc. Nutr. Soc. 2010, 69, 592-600. [CrossRef]

10. Haque, S.E. How Effective Are Existing Phosphorus Management Strategies in Mitigating Surface Water Quality Problems in the US? Sustainability 2021, 13, 6565. [CrossRef]

11. Peng, L.; Dai, H.; Wu, Y.; Peng, Y.; Lu, X. A comprehensive review of the available media and approaches for phosphorus recovery from wastewater. Water Air Soil Pollut. 2018, 229, 1-28. [CrossRef]

12. Powles, S.B.; Yu, Q. Evolution in action: Plants resistant to herbicides. Annu. Rev. Plant Biol. 2010, 61, 317-347. [CrossRef] [PubMed]

13. Asaduzzaman, M.; Pratley, J.E.; Luckett, D.; Lemerle, D.; Wu, H. Weed management in canola (Brassica napus L): A review of current constraints and future strategies for Australia. Archives Agron. Soil Sci. 2020, 66, 427-444. [CrossRef]

14. Guo, M.; Li, B.; Xiang, Q.; Wang, R.; Liu, P.; Chen, Q. Phosphite translocation in soybean and mechanisms of Phytophthora sojae inhibition. Pest. Biochem. Physiol. 2021, 172, 104757. [CrossRef] [PubMed]

15. García-Gaytán, V.; Hernández-Mendoza, F.; Coria-Téllez, A.V.; García-Morales, S.; Sánchez-Rodríguez, E.; Rojas-Abarca, L.; Daneshvar, H. Fertigation: Nutrition, stimulation and bioprotection of the root in high performance. Plants 2018, 7, 88. [CrossRef]

16. McDonald, A.E.; Grant, B.R.; Plaxton, W.C. Phosphite (phosphorous acid): Its relevance in the environment and agriculture and influence on plant phosphate starvation response. J. Plant Nutr. 2001, 24, 1505-1519. [CrossRef]

17. Solis-Palacios, R.; Hernández-Ramírez, G.; Salinas-Ruiz, J.; Hidalgo-Contreras, J.V.; Gómez-Merino, F.C. Effect and Compatibility of Phosphite with Trichoderma sp. Isolates in the Control of the Fusarium Species Complex Causing Pokkah Boeng in Sugarcane. Agronomy 2021, 11, 1099. [CrossRef]

18. Cerqueira, A.; Alves, A.; Berenguer, H.; Correia, B.; Gómez-Cadenas, A.; Diez, J.J.; Monteiro, P.; Pinto, G. Phosphite shifts physiological and hormonal profile of Monterey pine and delays Fusarium circinatum progression. Plant Physiol. Biochem. 2017, 114, 88-99. [CrossRef]

19. Rampersad, S.N. Pathogenomics and management of Fusarium diseases in plants. Pathogens 2020, 9, 340. [CrossRef]

20. Olivieri, F.P.; Feldman, M.L.; Machinandiarena, M.F.; Lobato, M.C.; Caldiz, D.O.; Daleo, G.R.; Andreu, A.B. Phosphite applications induce molecular modifications in potato tuber periderm and cortex that enhance resistance to pathogens. Crop Protect. 2012, 32, 1-6. [CrossRef]

21. Silva, O.; Santos, H.; Dalla Pria, M.; May-De Mio, L. Potassium phosphite for control of downy mildew of soybean. Crop Protect. 2011, 30, 598-604. [CrossRef]

22. Huang, Z.; Carter, N.; Lu, H.; Zhang, Z.; Wang-Pruski, G. Translocation of phosphite encourages the protection against Phytophthora infestans in potato: The efficiency and efficacy. Pest. Biochem. Physiol. 2018, 152, 122-130. [CrossRef] [PubMed]

23. Mehta, D.; Ghahremani, M.; Pérez-Fernández, M.; Tan, M.; Schläpfer, P.; Plaxton, W.C.; Uhrig, R.G. Phosphate and phosphite have a differential impact on the proteome and phosphoproteome of Arabidopsis suspension cell cultures. Plant J. 2021, 105, 924-941. [CrossRef] [PubMed] 
24. Thao, H.T.B.; Yamakawa, T. Phosphite (phosphorous acid): Fungicide, fertilizer or bio-stimulator? Soil Sci. Plant Nutr. 2009, 55, 228-234. [CrossRef]

25. César Bachiega Zambrosi, F.; Mattos, D.J.; Syvertsen, J.P. Plant growth, leaf photosynthesis, and nutrient-use efficiency of citrus rootstocks decrease with phosphite supply. J. Plant Nutr. Soil Sci. 2011, 174, 487-495. [CrossRef]

26. Xi, Y.; Han, X.; Zhang, Z.; Joshi, J.; Borza, T.; Aqa, M.M.; Zhang, B.; Yuan, H.; Wang-Pruski, G. Exogenous phosphite application alleviates the adverse effects of heat stress and improves thermotolerance of potato (Solanum tuberosum L.) seedlings. Ecotoxicol. Environ. Saf. 2020, 190, 110048. [CrossRef]

27. Leong, S.J.; Lu, W.-C.; Chiou, T.-J. Phosphite-mediated suppression of anthocyanin accumulation regulated by mitochondrial ATP synthesis and sugars in Arabidopsis. Plant Cell Physiol. 2018, 59, 1158-1169. [CrossRef]

28. Trejo-Téllez, L.I.; Estrada-Ortiz, E.; Gómez-Merino, F.C.; Becker, C.; Krumbein, A.; Schwarz, D. Flavonoid, nitrate and glucosinolate concentrations in Brassica species are differentially affected by photosynthetically active radiation, phosphate and phosphite. Front. Plant Sci. 2019, 10, 371. [CrossRef] [PubMed]

29. Burra, D.D. Defence Related Molecular Signalling in Potato. Acta Univ. Agric. Sueciae 2016, 7, 1652-6880.

30. Gómez-Merino, F.C.; Trejo-Téllez, L.I. Biostimulant activity of phosphite in horticulture. Sci. Hort. 2015, 196, 82-90. [CrossRef]

31. Han, X.; Xi, Y.; Zhang, Z.; Mohammadi, M.A.; Joshi, J.; Borza, T.; Wang-Pruski, G. Effects of phosphite as a plant biostimulant on metabolism and stress response for better plant performance in Solanum tuberosum. Ecotoxicol. Environ. Saf. 2021, $210,111873$. [CrossRef]

32. Gómez-Merino, F.C.; Trejo-Téllez, L.I. Conventional and novel uses of phosphite in horticulture: Potentialities and challenges. Italus Hortus 2016, 23, 1-13.

33. Quandahor, P.; Lin, C.; Gou, Y.; Coulter, J.A.; Liu, C. Leaf morphological and biochemical responses of three potato (Solanum tuberosum L.) cultivars to drought stress and aphid (Myzus persicae Sulzer) infestation. Insects 2019, 10, 435. [CrossRef]

34. Jia, H.; Wang, Q.; Tao, Q.; Xue, W. Analysis and circuit implementation for the fractional-order Chen system. In Proceedings of the 8th CHAOS Conference Proceedings, Paris, France, 26-29 May 2015.

35. Cabello, R.; De Mendiburu, F.; Bonierbale, M.; Monneveux, P.; Roca, W.; Chujoy, E. Large-scale evaluation of potato improved varieties, genetic stocks and landraces for drought tolerance. Am. J. Potato Res. 2012, 89, 400-410. [CrossRef]

36. Murashige, T.; Skoog, F. A revised medium for rapid growth and bio assays with tobacco tissue cultures. Physiol. Plant. 1962, 15, 473-497. [CrossRef]

37. Wilkins, D. The measurement of tolerance to edaphic factors by means of root growth. New Phytol. 1978, 80, 623-633. [CrossRef]

38. Dawuda, M.M.; Liao, W.; Hu, L.; Yu, J.; Xie, J.; Calderón-Urrea, A.; Jin, X.; Wu, Y. Root tolerance and biochemical response of Chinese lettuce (Lactuca sativa L.) genotypes to cadmium stress. PeerJ 2019, 7, e7530. [CrossRef]

39. Junglee, S.; Urban, L.; Sallanon, H.; Lopez-Lauri, F. Optimized assay for hydrogen peroxide determination in plant tissue using potassium iodide. Am. J. Analyt. Chem. 2014, 5, 730. [CrossRef]

40. Hodges, D.M.; DeLong, J.M.; Forney, C.F.; Prange, R.K. Improving the thiobarbituric acid-reactive-substances assay for estimating lipid peroxidation in plant tissues containing anthocyanin and other interfering compounds. Planta 1999, 207, 604-611. [CrossRef]

41. Dhindsa, R.S.; Plumb-Dhindsa, P.; Thorpe, T.A. Leaf senescence: Correlated with increased levels of membrane permeability and lipid peroxidation, and decreased levels of superoxide dismutase and catalase. J. Exp. Bot. 1981, 32, 93-101. [CrossRef]

42. Bates, L.S.; Waldren, R.P.; Teare, I. Rapid determination of free proline for water-stress studies. Plant Soil 1973, $39,205-207$. [CrossRef]

43. Pocketbook, F.S. World Food and Agriculture; Food and Agriculture Organization: Rome, Italy, 2015.

44. Vinocur, B.; Altman, A. Recent advances in engineering plant tolerance to abiotic stress: Achievements and limitations. Curr. Opin. Biotech. 2005, 16, 123-132. [CrossRef]

45. Zhu, J.-K. Plant salt tolerance. Trends Plant Sci. 2001, 6, 66-71. [CrossRef]

46. Ticconi, C.A.; Delatorre, C.A.; Abel, S. Attenuation of phosphate starvation responses by phosphite in Arabidopsis. Plant Physiol. 2001, 127, 963-972. [CrossRef] [PubMed]

47. Ram, B.; Fartyal, D.; Sheri, V.; Varakumar, P.; Borphukan, B.; James, D.; Yadav, R.; Bhatt, A.; Agrawal, P.K.; Achary, V.M.M. Characterization of phoA, a Bacterial Alkaline Phosphatase for Phi Use Efficiency in Rice Plant. Front. Plant Sci. 2019, 10, 37. [CrossRef] [PubMed]

48. Plaxton, W.C.; Carswell, M.C. Metabolic aspects of the phosphate starvation response in plants. In Plant Responses to Environmental Stresses; Routledge: Oxfordshire, UK, 2018; pp. 349-372.

49. Carswell, M.C.; Grant, B.R.; Plaxton, W.C. Disruption of the phosphate-starvation response of oilseed rape suspension cells by the fungicide phosphonate. Planta 1997, 203, 67-74. [CrossRef] [PubMed]

50. Vinas, M.; Mendez, J.C.; Jiménez, V.M. Effect of foliar applications of phosphites on growth, nutritional status and defense responses in tomato plants. Sci. Hort. 2020, 265, 109200. [CrossRef]

51. Lambers, H.; Plaxton, W.C. Phosphorus: Back to the roots. Annu. Plant Rev. 2015, 48, 3-22.

52. Devaiah, B.N.; Karthikeyan, A.S.; Raghothama, K.G. WRKY75 transcription factor is a modulator of phosphate acquisition and root development in Arabidopsis. Plant Physiol. 2007, 143, 1789-1801. [CrossRef]

53. Correa, J.; Postma, J.A.; Watt, M.; Wojciechowski, T. Soil compaction and the architectural plasticity of root systems. J. Exp. Bot. 2019, 70, 6019-6034. [CrossRef] 
54. Vanhees, D.J.; Loades, K.W.; Bengough, A.G.; Mooney, S.J.; Lynch, J.P. The ability of maize roots to grow through compacted soil is not dependent on the amount of roots formed. Field Crop. Res. 2021, 264, 108013. [CrossRef]

55. Polania, J.; Rao, I.M.; Cajiao, C.; Grajales, M.; Rivera, M.; Velasquez, F.; Raatz, B.; Beebe, S.E. Shoot and root traits contribute to drought resistance in recombinant inbred lines of MD 23-24× SEA 5 of common bean. Front. Plant Sci. 2017, 8, 296. [CrossRef]

56. Varadarajan, D.K.; Karthikeyan, A.S.; Matilda, P.D.; Raghothama, K.G. Phosphite, an analog of phosphate, suppresses the coordinated expression of genes under phosphate starvation. Plant Physiol. 2002, 129, 1232-1240. [CrossRef] [PubMed]

57. Lee, T.M.; Tsai, P.F.; Shyu, Y.T.; Sheu, F. The Effects of Phosphite on Phosphate Starvation Responses of Ulva Lactuca (Ulvales, Chlorophyta) 1. J. Phycol. 2005, 41, 975-982. [CrossRef]

58. Schroetter, S.; Angeles-Wedler, D.; Kreuzig, R.; Schnug, E. Effects of phosphite on phosphorus supply and growth of corn (Zea mays). Landbauforsch. Volkenrode 2006, 56, 87.

59. Thao, H.T.B.; Yamakawa, T.; Myint, A.K.; Sarr, P.S. Effects of phosphite, a reduced form of phosphate, on the growth and phosphorus nutrition of spinach (Spinacia oleracea L.). Soil Sci. Plant Nutrit. 2008, 54, 761-768. [CrossRef]

60. Avila, F.W.; Faquin, V.; Araujo, J.L.; Marques, D.J.; Júnior, P.M.R.; da Silva Lobato, A.K.; Ramos, S.J.; Baliza, D.P. Phosphite supply affects phosphorus nutrition and biochemical responses in maize plants. Aust. J. Crop Sci. 2011, 5, 646-653.

61. Zambrosi, F.C.B.; Mattos, D., Jr.; Quaggio, J.A.; Cantarella, H.; Boaretto, R.M. Phosphorus uptake by young citrus trees in low-P soil depends on rootstock varieties and nutrient management. Commun. Soil Sci. Plant Anal. 2013, 44, 2107-2117. [CrossRef]

62. Hirosse, E.H.; Creste, J.E.; Custódio, C.C.; Machado-Neto, N.B. In vitro growth of sweet potato fed with potassium phosphite. Acta Scient. Agron. 2012, 34, 85-91. [CrossRef]

63. Balemi, T.; Negisho, K. Management of soil phosphorus and plant adaptation mechanisms to phosphorus stress for sustainable crop production: A review. J. Soil Sci. Plant Nutrit. 2012, 12, 547-562. [CrossRef]

64. Richardson, A.E.; Barea, J.-M.; McNeill, A.M.; Prigent-Combaret, C. Acquisition of phosphorus and nitrogen in the rhizosphere and plant growth promotion by microorganisms. Plant Soil 2009, 321, 305-339. [CrossRef]

65. Lambers, H.; Clode, P.L.; Hawkins, H.J.; Laliberté, E.; Oliveira, R.S.; Reddell, P.; Shane, M.W.; Stitt, M.; Weston, P. Metabolic adaptations of the non-mycotrophic Proteaceae to soils with low phosphorus availability. Annu. Plant Rev. Phosphorus Metab. Plants 2015, 48, 289.

66. Wang, Y.; Yang, R.; Zheng, J.; Shen, Z.; Xu, X. Exogenous foliar application of fulvic acid alleviate cadmium toxicity in lettuce (Lactuca sativa L.). Ecotoxico. Environ. Saf. 2019, 167, 10-19. [CrossRef] [PubMed]

67. Pandey, R.; Meena, S.K.; Krishnapriya, V.; Ahmad, A.; Kishora, N. Root carboxylate exudation capacity under phosphorus stress does not improve grain yield in green gram. Plant Cell Rep. 2014, 33, 919-928. [CrossRef]

68. Gahoonia, T.S.; Nielsen, N.E. Root traits as tools for creating phosphorus efficient crop varieties. Plant Soil 2004, $260,47-57$. [CrossRef]

69. Wu, P.; Ma, X.; Tigabu, M.; Wang, C.; Liu, A.; Oden, P.C. Root morphological plasticity and biomass production of two Chinese fir clones with high phosphorus efficiency under low phosphorus stress. Can. J. For. Res. 2011, 41, 228-234. [CrossRef]

70. Tripathi, D.K.; Singh, S.; Singh, V.P.; Prasad, S.M.; Dubey, N.K.; Chauhan, D.K. Silicon nanoparticles more effectively alleviated UV-B stress than silicon in wheat (Triticum aestivum) seedlings. Plant Physiol. Biochem. 2017, 110, 70-81. [CrossRef] [PubMed]

71. Zhang, F.; Zhang, H.; Wang, G.; Xu, L.; Shen, Z. Cadmium-induced accumulation of hydrogen peroxide in the leaf apoplast of Phaseolus aureus and Vicia sativa and the roles of different antioxidant enzymes. J. Haz. Mat. 2009, 168, 76-84. [CrossRef] [PubMed]

72. Oyarburo, N.S.; Machinandiarena, M.F.; Feldman, M.L.; Daleo, G.R.; Andreu, A.B.; Olivieri, F.P. Potassium phosphite increases tolerance to UV-B in potato. Plant Physiol. Biochem. 2015, 88, 1-8. [CrossRef]

73. Ramos, S.; Faquin, V.; Guilherme, L.; Castro, E.; Ávila, F.; Carvalho, G.; Bastos, C.; Oliveira, C. Selenium biofortification and antioxidant activity in lettuce plants fed with selenate and selenite. Plant Soil Environ. 2010, 56, 584-588. [CrossRef] 